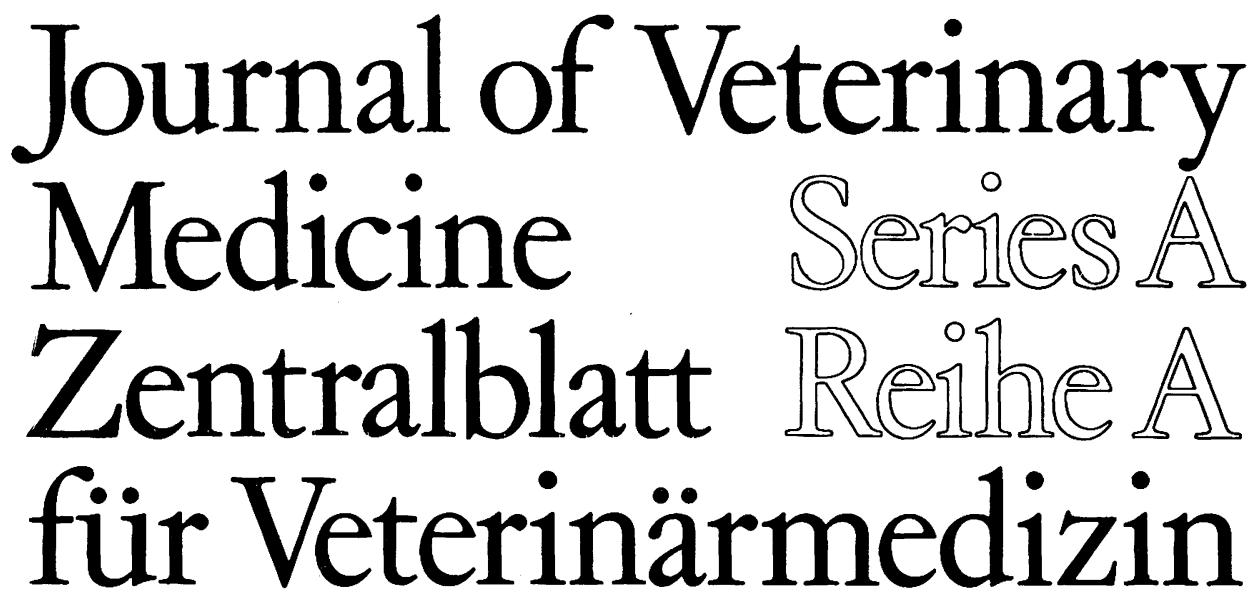

Physiology, Pathology, Clinical Medicine

Edited by / Herausgegeben von

$\begin{array}{lllll}\text { O.-R. KaAden } & \text { A.Mayr } & \text { E.SCHARRER } & \text { B.SChIEFER } & \text { H.SPÖRRI } \\ \text { München } & \text { München } & \text { Zürich } & \text { Saskatoon } & \text { Zürich }\end{array}$

VOLUME/BAND 38, 1991

302 Figures/Abbildungen

189 Tables/Tabellen

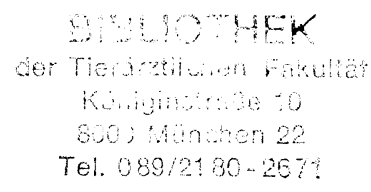

(10) PAV Scientific Publishers Berlin and Hamburg 


\section{Index Vol. 38 \\ Inhaltsverzeichnis zum achtunddreißigsten Band}

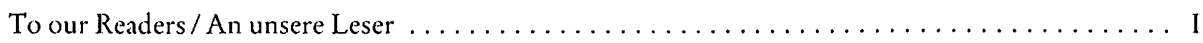

\section{Review Articles / Review-Artikel}

Daniel, R. C. W., see Hussain and Daniel ........................... 641

Ekfalck, A., B. Jones and N. Obel: Possible Importance for Laminitis Research of Recent

Studies on Substances Influencing the Differentiation of Cultured Keratinocytes . . . . . 72

Hussain, A.M., and R.C.W. Daniel: Bovine Endometritis: Current and Future Alternative

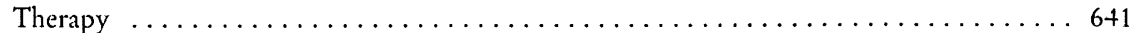

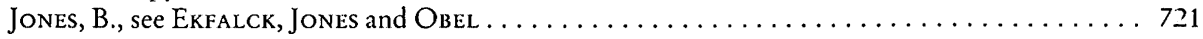

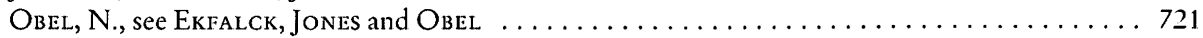

\section{Original Papers / Originalarbeiten}

Abdel-Fattah, Kamal I., S. Bobek and A. Sechman: Serum Pattern of Thyroxine $\left(\mathrm{T}_{4}\right), 3,3^{\prime}, 5$ -

Triiodothyronine $\left(\mathrm{T}_{3}\right)$ and 3,3',5'-Triiodothyronine $\left(\mathrm{rT}_{3}\right)$ in Fed and Fasted Cocks

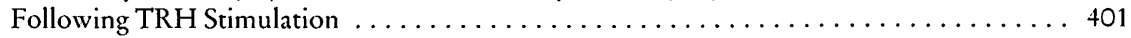

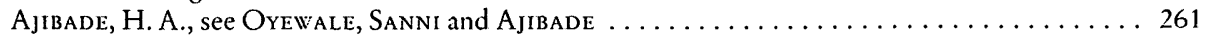

Albihn, Ann: Standing Oestrus, Ovarian Function and Early Pregnancy in Virgin and Repeat

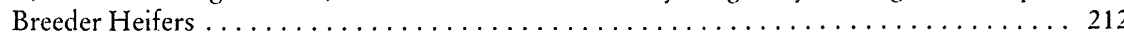

Albihn, A., see also Stanchev, Rodriguez-Martinez, Albihn, Eriksson, Gustafsson and

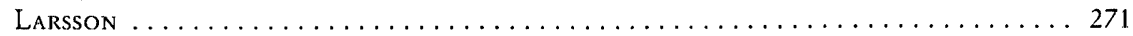

Amory, H., A. Linden, D. Desmecht, F. Rollin, B. Genicot and P. Lekeux: Validation of the

Thermodilution Technique for the Estimation of the Cardiac Output in the Unsedated

Calf ........................................... 409

Amory, H., see also Art, Desmecht, Amory and Lekeux ................. 148

Amory, H., see also Linden, Art, Amory, Massart, Burvenich and Lekeux . . . . . . . 376

Andersson, L., see Forshell., Andersson and Pehrson ..................... 608

Anjiki, T., G. Takeya, N. Hashimoto and K. Kadota: An Ultrastructural Study of Vulval

Myofibroblastoma in a Cow .................................. 770

Arbetter, K., M. Dobretsberger, Erika Müller und A. Holzmann: Ein indirekter Nachweis

der Ovulation und Fertilisation beim Hund durch Progesteronverlaufsuntersuchungen.

(About an Indirect Proof of Ovulation and Ovafertilisation in Dogs by Continued

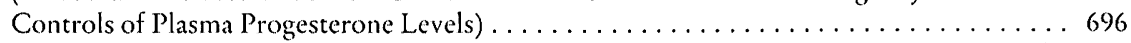

Art, T., D. Desmecht, H.Amory and P. Lekeux: Lobeline-Induced Hyperpnea in Equids.

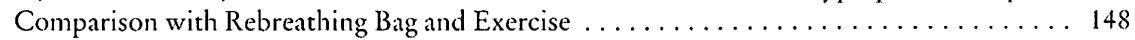

Art, T., see also Linden, Art, Amory, Massart, Burvenich and Lekeux . . . . . . . . 376

Axelsson, S.: Origin and Significance of Acetylcholine and Choline in Plasma and Serum from

Normal and Paretic Cows . . . . . . . . . . . . . . . . . . . . . 737

Ayers, J., see Troyer, Ayers, Wollen, Leipold and CoOK ................. 300

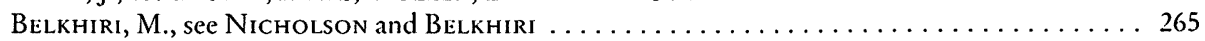

Bestmann, M., see Gäbel, Bestmann and Martens $\ldots \ldots \ldots \ldots \ldots \ldots \ldots \ldots \ldots \ldots \ldots \ldots \ldots$

Bobek, S., see Abdel-Fattah, Bobek and Sechman ..................... 401

BonDurant, R. H., see Giri, Stabenfeldt, Moseley, Graham, Bruss, BonDurant, Cullor

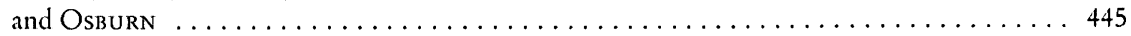

Braun, U., R. Eicher and F. Ehrensperger: Type 1 Abomasal Ulcers in Dairy Cattle . . . . . . 357

BROZ, J., see WANNER, WALKER, SUTTER, RIOND and BROZ . . . . . . . . . . . . . 755

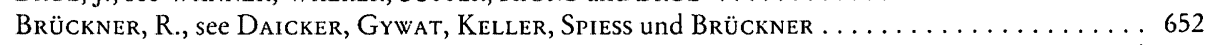

Bruss, M.L., see Giri, Stabenfeldt, Moseley, Graham, Bruss, BonDurant, Cullor and

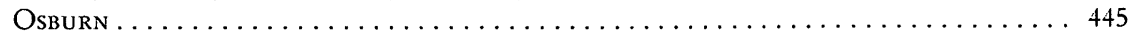

Burtscher, H., see Mayr, Gilli, Schleger, Reifinger and Burtscher . . . . . . . . . 141

Burvenich, C., see Linden, Art, Amory, Massart, Burvenich and Lekeux . . . . . . . . 376 
Bushnell, R. B., see Rose, Giri, Cullor and Bushnelt. $\ldots \ldots \ldots \ldots \ldots \ldots \ldots \ldots$

ButTENSCHON, J.: Statistical Evidence for a Link between Bronchopneumonia and Disseminated

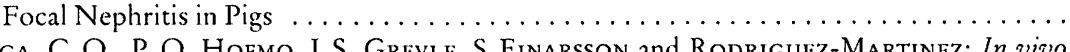

Bwanga, C. O., P. O. Hofmo, I. S. Grevle, S. Einarsson and Rodriguez-Martinez: In vivo Fertilizing Capacity of Deep Frozen Boar Semen Packaged in Plastic Bags and Maxi-

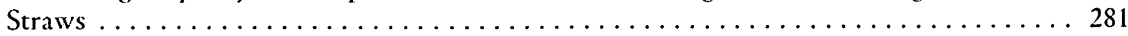

Camón-Urgel, J., see López-Gatius and Camón-Urgel $\ldots \ldots \ldots \ldots \ldots \ldots \ldots \ldots \ldots \ldots \ldots$

Chauvet, A., see Rousseaux, Olkowski, Chauvet, Gooneratne and Christenson . . . . . . 229

Christenson, D. A., see Rousseaux, Olkowski, Chauvet, Gooneratne and Christenson .. 229

Cihak, J., H.W.L. Ziegler-Heitbrock, H.Stein and U.Lösch: Effect of Perinatal Anti-

TCR2 Treatment and Thymectomy on Serum Immunoglobulin Levels in the Chicken . . . 28

Cook, J.E., see Troyer, Ayers, Wollen, Leipold and CoOK ................ 300

Cools, V., see Cox, Schrauwein, Cools and Houvenaghel ................ 418

Cordeiro, A., see Cornejo, López, Pokniak, González and Cordeiro . . . . . . . . . 126

Cornejo, S., A. López, J. Pokniak, N. González and A. Cordeiro: Effect of Energy / Protein Ratio on Productive Performance and Carcass Composition of Male Broilers . . . . . . 126

Cox, E., E.Schrauwein, V. Cools and A. Houvenaghel: Experimental Induction of Diar-

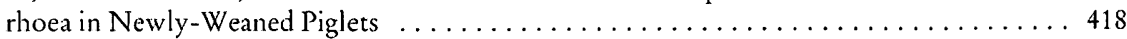

Cullor, J.S., see Rose, Giri, Cullor and Bushnell . . . . . . . . . . . . . . . 99

Cullor, J.S., see also Giri, Stabenfeldt, Moseley, Graham, Bruss, BonDurant, Cullor

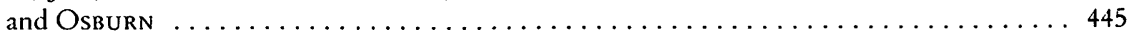

Dafalla, E. A., see Ramadan, Gameel, Dafalla and Galil ................. 441

Daicker, B., L. Gywat, M. Keller, B. Spiess und R. Brückner: Adenome des Irispigmentepithels mit Endothelialisation und Descemetisation beim Pferd. (Adenomas of the Iris Pigment Epithelium with Endothelialization and Descemetization in a Horse) . . . . . . . .

Dalin, A.-M., see Hurst, Dalin and Rodriguez-Martiniz . . . . . . . . . . . . . . . 594

Dämmrich, K., see Zentek, Dämmrich und Meyer . . . . . . . . . . . . . . . . . . . 561

Daniel, R. C. W., see Fenwick and Daniel .......................... 485

Degòrski, A., see Lechowski, Lenarcik, Degòrski and Winnicka ............... 530

Denac, M., G. Kümin and E. Scharrer: Effect of Noradrenaline on Smooth Muscle Strips from the Reticular Groove of Adult Cattle . . . . . . . . . . . . . . . . . . . . . . . . 383

Desmecht, D., see Art, Desmecht, Amory and Lekeux . . . . . . . . . . . . . . . . 148

Desmecht, D., see also Amory, Linden, Desmecht, Rollin, Genicot and Lekeux . . . . . . . 409

Dijk, E. van, see Egberts, Vellenga, van Dijk and Mouwen ................... 157

Distr, O., W. Grussler, J.SChwarz und H. Kräusslich: Analyse umweltbedingter und genetischer Einflüsse auf die Häufigkeit von Hüftgelenksdysplasie beim Deutschen Schäferhund. (Analysis of environmental and genetic influences on the frequency of hip dysplasia in German shepherd dogs) . . . . . . . . . . . . . . . . . . . . . . 460

Dobretsberger, M., see Arbeiter, Dobretsberger, Müller und Holzmann . . . . . . . . 696

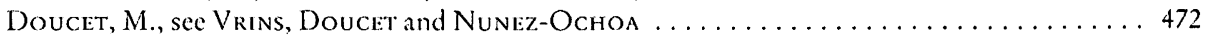

Eder, H., see Fuchs und Eder . . . . . . . . . . . . . . . . . . . . . 749

Egberts, H.J. A., L. Vellenga, J. E. van Dijk and J. M. V. M. Mouwen: Intestinal Permeability in Piglets During Transmissible Gastroenteritis . . . . . . . . . . . . . . . 157

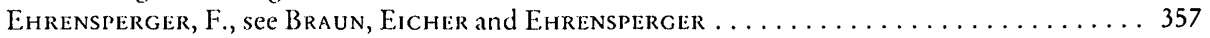

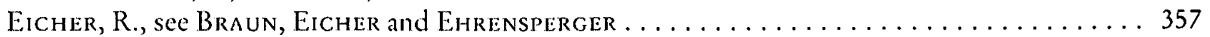

Einarsson, S., see Bwanga, Hofmo, Grevle, Einarsson and Rodrigulz-Martinez . . . . . 281

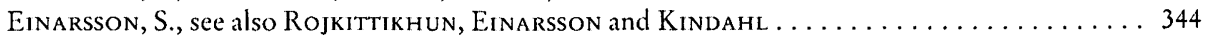

Einarsson, S., see also Pettersson, Larsson and Einarsson .................. 481

Einarsson, S., see also Söderquist, Janson, Larsson and Einarsson . . . . . . . . . . . 534

Erben, R. G., see Kohn, Erben, Weiser, Rambeck and Zucker ................ 54

ERHARD, M., J. Keller, R. KühLmann and U. Lösch: Influence of Various Adjuvants on the Synthesis of Specific Antibodies of Chicken, Sheep and Rabbit Following Immunization

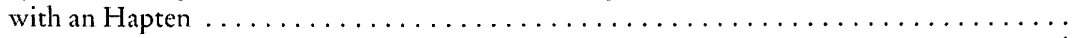

Eriksson, H., see Stanchev, Rodriguez-Martinez, Albihn, Eriksson, Gustafsson and

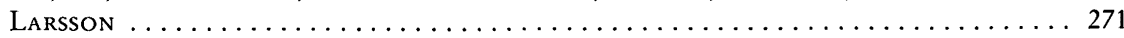

Errecalde, J.O., C.E. Lanusse, O.N. Mestorino, M.F. Landoni and A. L. Soraci: Pharmacokinetics of Ticarcillin and Ticarcillin-Probenecid in Sheep . . . . . . . . . 255

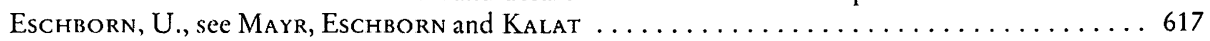

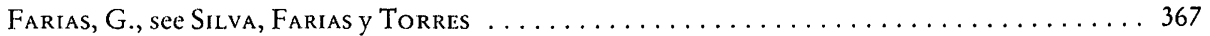

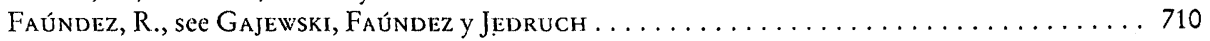


FEnwick, D.C., and R.C.W. Daniel: Monthly Variation and Distribution of Erythrocyte Na, $\mathrm{K}$ and $\mathrm{Mg}$ Concentrations in Normal Dairy Cows ................... 485

Fuchs, A., und H. Eder: Zahl und Reifegradverteilung der Retikulozyten von sechs Tierarten . 749 Gäbel, G., Maren Bestmann and H. Martens: Influences of Diet, Short-Chain Fatty Acids, Lactate and Chloride on Bicarbonate Movement across the Reticulo-Rumen Wall of Sheep

Gajewski, Z., R. Faúndez y J. Jedruch: Efécto de la Acción de Estimulantes y Bloqueadores de los Receptores Adrenérgicos sobre la Actividad Eléctrica del Utero en Vacas Preñadas. (Effects of Adrenergic Stimulants and Blockers on the Electrical Activity of the Uterus in

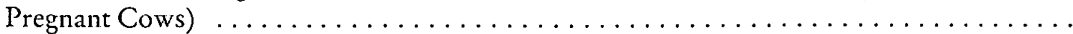

Gameel, A. A., see Ramadan, Gameel, Dafalla and Galil . . . . . . . . . . . . .

Ganter, M., und Marion Kanngiesser: Auswirkung von Ketamin und dessen Kombinationen mit Xylazin und Climazolam auf Kreislauf und Atmung beim Schwein. (Cardiopulmonary Responses to Ketamine- $\mathrm{HCl}$ and its Combinations with Xylazine and with Climazolam in

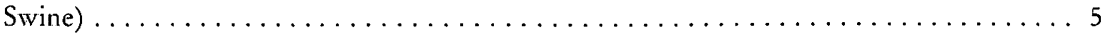

Gasthuys, F., A. De Moor and D. Parmentier: Haemodynamic Effects of Change in Position and Respiration Mode during a Standard Halothane Anaesthesia in Ponies ............

Gasthuys, F., A. DE Moor and D. Parmentier: Influence of Dopamine and Dobutamine on the Cardiovascular Depression During a Standard Halothane Anaesthesia in Dorsally Recum-

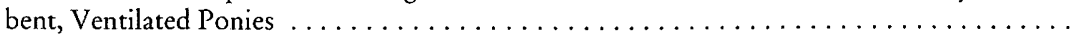

Gasthuys, F., A. De Moor and D. Parmentrer: Influence of Digoxin Followed by Dopamine on the Cardiovascular Depression During a Standard Halothane Anaesthesia in Dorsally

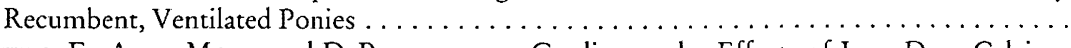

Gasthuys, F., A. De Moor and D. Parmentier: Cardiovascular Effects of Low Dose Calcium Chloride Infusions During Halothane Anaesthesia in Dorsally Recumbent Ventilated

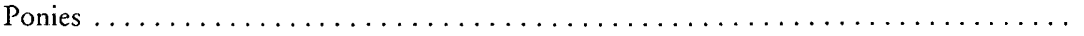

Genicot, B., F. Mouligneau und P. Lekeux: Wirksamkeit eines oralen Beruhigungsmittels auf das Verhalten und die zootechnischen Leistungen von Mastbullen der Weiß-Blauen Belgischen Rasse. (Efficiency of a Sedative on the Behaviour and the Performances of Belgian White and Blue Double-Muscled Cattle during Fattening) $\ldots \ldots \ldots \ldots \ldots 668$

Genicot, B., see also Amory, Linden, Desmecht, Rollin, Genicot and Lekeux . . . . . . . . 409

Gilli, H., see Mayr, Gilli, Schleger, Reifinger and Burtscher . . . . . . . . . . . . 141

Grri, S. N., G.H. Stabenfeldt, T.A. Moseley, T.W. Graham, M.L. Bruss, R. H. Bon Durant, J.S. Cullor and B.I. Osburn: Role of Eicosanoids in Abortion and its Prevention by Treatment with Flunixin Meglumine in Cows During the First Trimester of

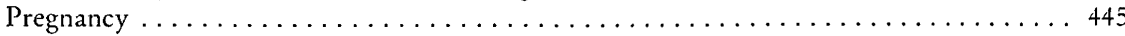

Giri, S. N., see also Rose, Giri, Cullor and Bushnell . . . . . . . . . . . . . . . 99

Gogoi, S. N., J.M. Nigam, P. K. Peshin, D. Sharifi and D. B. Patil: Studies on Intravenous Regional Analgesia of the Hind Limb in the Bovine . . . . . . . . . . . . . . . . . 544

Goldberg, M., and M. Koller: Concentrations and Patterns of Released Pterins of Various

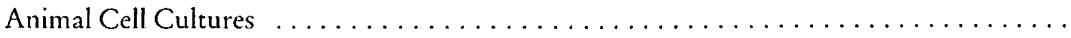

González, N., see Cornejo, López, Pokniak, González and Cordeiro . . . . . . . . . 126

Gooneratne, S. R., see Rousseaux, Olkowski, Chauvet, Gooneratne and Christenson . . 229

Graf, F., D. Schams, J. Meyer and H. Kräusslich: Effect of Recombinant Bovine Somatotropin (BST) on Physiological Parameters and on Milk Production in German Fleckvieh

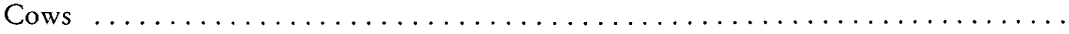

Graham, T. W., see Giri, Stabenfeldt, Moseley, Graham, Bruss, BonDurant, Cullor and

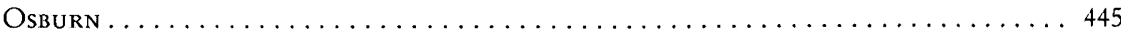

Grevle, I.S., see Bwanga, Hofmo, Grevle, Einarsson and Rodriguez-Martinez . . . . . . 281

Gruber, F. P., see Hins und Gruber $\ldots \ldots \ldots \ldots \ldots \ldots \ldots \ldots \ldots \ldots \ldots \ldots \ldots \ldots \ldots \ldots \ldots \ldots \ldots \ldots$

Grussler, W., see Distl, Grussler, Schiwarz und Kräusslich . . . . . . . . . . . 460

Gustafsson, H., see Stanchev, Rodriguez-Martinez, Albihn, Eriksson, Gustafsson and

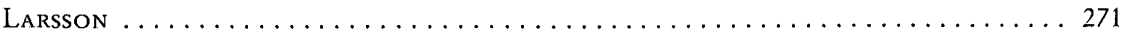

Gywat, L., see Daicker, Gywat, Keller, Spiess und Brückner ................. 652

Harmeyer, J., and T.Michalowski: A Technique for the Collection of Reticular Effluent of Sheep .......................................... 107

Hashimoto, N., see Anjiki, TAKeya, Hashimoto and Kadota . . . . . . . . . . . . . . 770

Hegel, G. v., see Schweigert, Uehlin-Harrell, v. Hegel and Wiesner . . . . . . . . 35

Hellmann, J., and H. Loppnow: Hyperplasia of Somatostatin and Pancreatic Polypeptide Immunoreactive Cells in Dogs with Idiopathic Atrophy of the Exocrine Pancreas . . . . . . 80

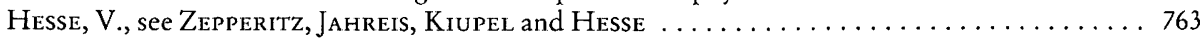


Heydner, Ch., see Kaltner, Heydner and Wittmann

Hins, J., und F.P. Gruber: Genetisches Fingerprinting von Inzuchtlinien, Auszuchten, transgenen Individuen und 3T3-Zellen von Mus musculus mit der Sonde B.E.S.T. MZ 1.3. (Genetic monitoring of inbred and outbred strains, transgenic individuals and 3T3-cells of

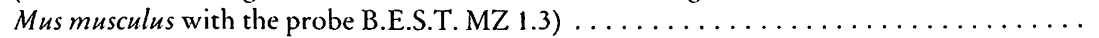
Hofmo, P. O., see Bwanga, Hofmo, Grevle, Einarsson and Rodriguez-Martinez . . . . . . Holzmann, A., see Arbeiter, Dobretsberger, Müller und Holzmann . . . . . . . . . . . 696 Houvenaghel, A., see Cox, Schrauwein, Cools and Houvenaghel ............. 418 Hurst, M., A.-M. Dalin and H.Rodriguez-Martinez: Embryonic Development of the

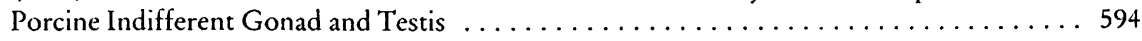

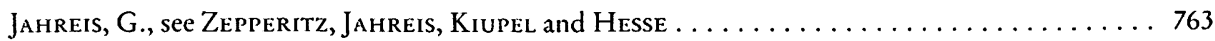

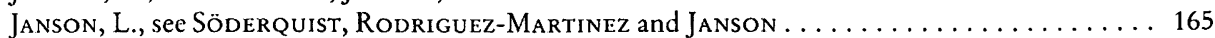

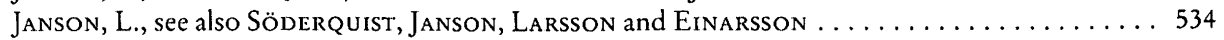

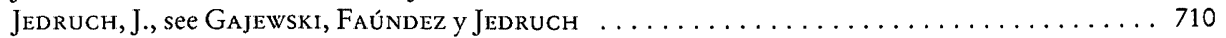

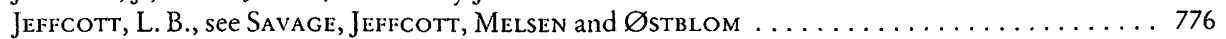

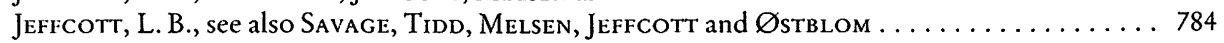

JefFcott, L. B., see also Savage, Tidd, Østblom, Melsen and JefFcotr . . . . . . . . . . 793

Jensen, A. L.: An Automated Method for Determination of Total Bile Acid Concentration in

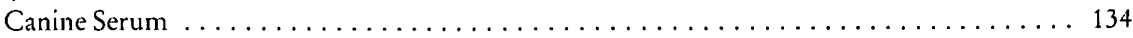

Jensen, A. L., and O. L. Nielsen: Chronic Hepatitis in Three Young Standard Poodles . . . . . . 194

Jensen, A. L.: Variations in Total Bile Acid Concentration in Serum of Dogs after a Test Meal . . 241

Jensen, A. L.: Evaluation of Fasting and Postprandial Total Serum Bile Acid Concentration in

Dogs with Hepatobiliary Disorders . . . . . . . . . . . . . . . . . . . . . . .

Johannsen, U., Solveig Menger, J. Kinne, R. Neumann, G. Mehlhorn und H. Prützner:

Untersuchungen zur Pathologie und Pathogenese der experimentellen Mycoplasma byorbinis-Infektion der Ferkel ohne und mit thermomotorischer Belastung. 2. Mitteilung: Elektronenmikroskopische Untersuchungsergebnisse. (Investigations on Pathology and Pathogenesis of Experimental Mycoplasma hyorbinis Infection in Piglets with or without

Thermomotoric Stress. 2. Results of electron microscopic studies) . . . . . . . . 321

Johannsen, U., see also Kinne, Johannsen, Neumann, Mehlhorn and Pfützner . . . . . 306

Kadota, K., see Anjiki, Takeya, Hashimoto and Kadota . . . . . . . . . . . . . 770

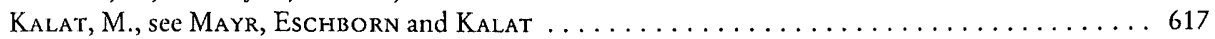

Kaltner, H., Ch. Heydner and J. Wittmann: The Influence of Thiourea on the Development

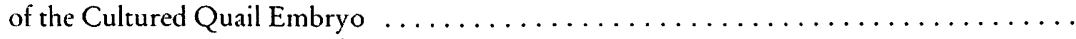

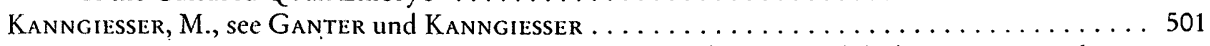

Kaspers, B., I. Schranner und U. LöSCH: Distribution of Immunoglobulins During Embryo-

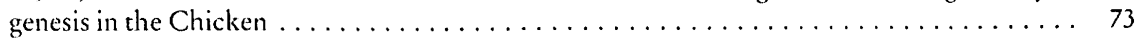

Kellek, M., see Daicker, Gywat, Keller, Spiess und Brückner . . . . . . . . . . . . 652

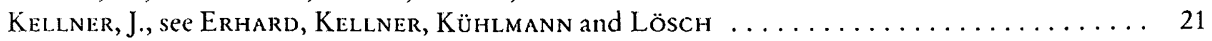

Kindahl, H., see Rojkittikhun, Einarsson and Kindahl ................ 344

Kinne, J., U. Johannsen, R. Neumann, G. Mehlhorn und H. Prützner: Untersuchungen zur Pathologie und Pathogenese der experimentellen Mycoplasma byorhinis-Infektion von Ferkeln ohne und mit thermomotorischer Belastung. 1. Mitteilung: Pathologischanatomische, -histologische und immunmorphologische Untersuchungsergebnisse. (Investigations on the Pathology and Pathogenesis of Experimental Mycoplasma byorbinis Infection of Piglets with or without thermomotoric Stress. 1. Results of Pathomorphologi-

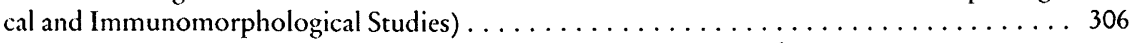

Kinne, J., see Johannsen, Menger, Kinne, Neumann, Mehlhorn und Pfützner . . . . . . . 321

Kiupel, H., see Zeppleritz, Jahreis, Kiupel and Hesse . . . . . . . . . . . . . . 763

Kohn, B., R.G. Erben, H.Weiser, W.A. Rambeck and H. Zucker: Osteopenia Caused by Ovariectomy in Young Female Rats and Prophylactic Effects of 1,25-dihydroxyvitamin $D_{3}$

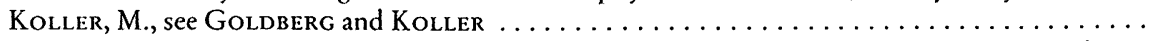

Köllıng, K.: Die ionisierte Calciumfraktion des Blutes: Abhängigkeit von verschiedenen methodischen Faktoren. (The Ionized Calcium Fraction of Blood: Dependence on Various

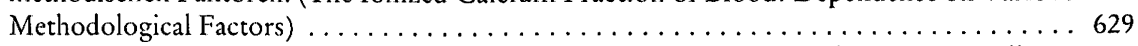

Kostka, V., M.-E. Krautwald-Junghanns and B. Tellmelm: Radiology of the Avian Skull . . 175 Kräusslich, H., see Distr, Grussler, SChwarz und Kräusslich . . . . . . . . . . . . 460

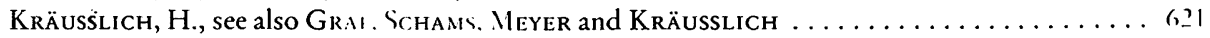

Krautwald-Junghanns, M.-F.., see Kostka, Krautwald-Junghanns and Tellhelm $\ldots \ldots \ldots$

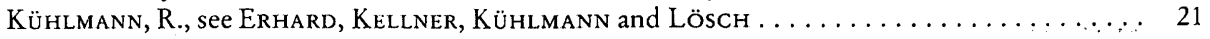


Kukkonen, S. A., see Miettinen, Rainio, Kukkonen and Setälä . . . . . . . . . . . 427

Kukulska, W., see Motyl, Siwecka, Kukulska, Orzechowski and Puchala . . . . . . . . 198

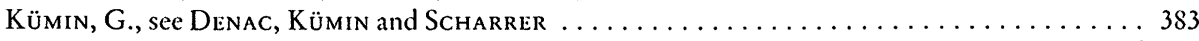

Lahrmann, K.H., and Barbara Staudt: Blockwirbelbildung beim Schwein. (Formation of Block Vertebrae in Swine) . . . . . . . . . . . . . . . . . . . . . . . . . . 691

Landoni, M. F., see Errecalde, Lanusse, Mestorino, Landoni and Soraci . . . . . . . 255

Langhans, W., E.Scharrer and A.H. Meyer: Changes in Feeding Behavior and Plasma Vasopressin Concentration during Water Deprivation in Goats . ............. 11

Lanusse, C. E., see Errecalde, Lanusse, Mestorino, Landoni and Soraci . . . . . . . . . 255

Larsson, B., see Pettersson, Larsson and Einarsson . . . . . . . . . . . . . . . . 481

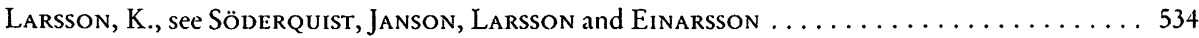

Lavin, S., F.J. Mora, L. Monreal and L.Viñas: Evaluation of a Haematological Analyser for its Use in Canine Clinical Pathology . . . . . . . . . . . . . . . . . . . . . . . 702

Lechowski, R., M. L.enarcik, A. Degorski and A. Winnicka: Serum Lysozyme Activity and Nitroblue Tetrazolium Reduction Test in Dogs with Diabetes Mellitus . . . . . . . . . . . 530

Leipold, H. W., see Troyer, Ayers, Wollen, Leipold and Cook . . . . . . . . . . . 300

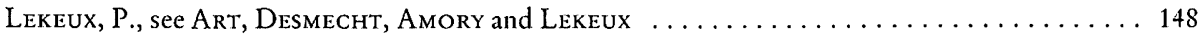

Lekeux, P., see also Linden, Art, Amory, Massart, Burvenich and Lekeeux … . . . . . 376

Lekeux, P., see also Amory, Linden, Desmecht, Rollin, Genicot and Lekeux . . . . . . . . . . . 409

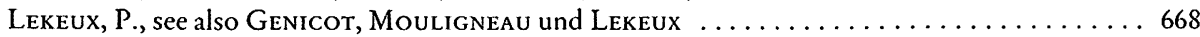

Lenarcik, M., see Lechowski, LenARcik, Degorski and WinNicka .............. 530

Linden, A., T. Art, H.Amory, A.M. Massart, C. Burvenich and P. Lekeux: Quantitative Buffy Coat Analysis Related to Adrenocortical Function in Horses During a Three-Day

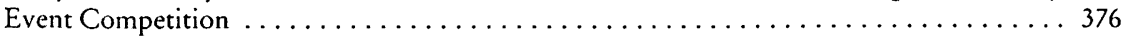

Linden, A., see also Amory, Linden, Desmecht, Rollin, Genicot and Lekeux . . . . . . . . . 409

LindNER, A.: Einfluß von Lagerungsdauer, -temperatur und Probenausgangsmaterial auf klinisch-chemische Blutvariablen. (Effect of temperature and duration of storage on clinico-chemical variables in different blood sample materials) $\ldots \ldots \ldots \ldots \ldots \ldots \ldots 433$

López, A., see Cornejo, López, Pokniak, González and Cordeiro . . . . . . . . . . . . 126 López-Gatius, F., and J.Camón-Urgel: Confirmation of Estrus Rates by Palpation per

Rectum of Genital Organs in Normal Repeat Dairy Cows . . . . . . . . . . . . . . 553

Loppnow, H., see Hellmann and Loppnow . . . . . . . . . . . . . . . . . . 80

Lösch, U., see Erhard, Kellner, Kühlmann and Lösch $\ldots \ldots \ldots \ldots \ldots \ldots \ldots \ldots \ldots \ldots \ldots \ldots \ldots$

Lösch, U., see also Cihak, Ziegler-Heitbrock, Stein and LösCh $\ldots \ldots \ldots \ldots \ldots \ldots \ldots$

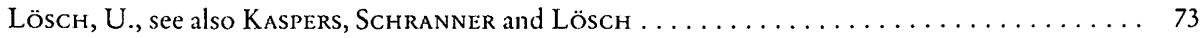

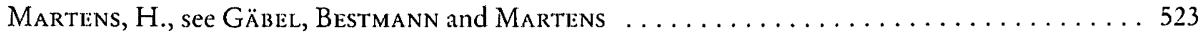

Massart, A. M., see Linden, Art, Amory, Massart, Burvenich and Lekeux . . . . . . . . 376

Mayr, B., H. Gilli, W. Schleger, M. Reifinger and H. Burtscher: Cytogenetic Characterization of Mammary Tumors in Two Domestic Dogs . . . . . . . . . . . . . . . 141

MaYr, B., U. Eschborn and M. Kalat: Near Triploidy in a Feline Fibrosarcoma . . . . . . 617

Mrassa, G.K., and J.S.D. Poulsen: Comparison between a Modified Haemocytometric

Technique and Electronic Counters in Goat Blood Cell Counting .............. 350

Mbassa, G. K., and J. S. D. Poulsin: Leukocyte Profile in Growing Dwarf and Landrace Kids .. 389

Mbassa, G. K., and J.S.D. Poulsen: Haematological Profile in Neonatal Dwarf and Landrace Kids ...................................... 510

Mbassa, G.K., and J.S.D. Poulsen: Profile of Some Plasma Enzyme Activities in Growing Dwarf and Landrace Kids .................................... 571

Mbassa, G. K., and J.S. D. Poulsen: Profiles of Some Clinical Chemical Parameters in Growing Dwarf and Landrace Kids . . . . . . . . . . . . . . . . . . . . 676

McEwan, G. T. A., B. Schousboe and E. Skadhauge: Influence of Age on Antisecretory Factor Inhibition of Enterotoxin Action in the Pig Small Intestine . . . . . . . . . . 222

Mehlhorn, G., see Kinne, Johannsen, Neumann, Mehlhorn and Pl:ützner … . . . . 306 Mehlhorn, G., see also Johannsen, Menger, Kinne, Neumann, Mehlhorn und Prützner . . 3.I Melsen, F., see Savage, Jeffcott, Melsen and Østblom ..................... 776 Melsen, F., see also Savage, Tidv, Melsen, Jeff.cott and Østblom . . . . . . . . . . . 784

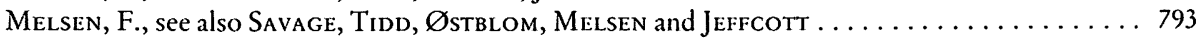
Menger, S., see Johannsen, Menger, Kinne, Neumann, Mehlmorn and Pfützner . . . . . 321 Mestorino, O. N., see Errecalde, Lanusse, Mestorino, Landoni and Soraci . . . . . . . . 255 Meyer, A. H., see Langhans, Scharrer and Meyer ....................... 11

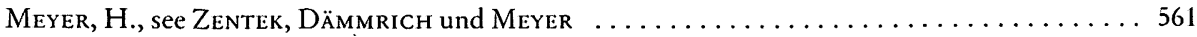




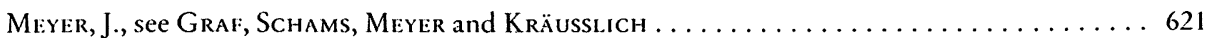

Michalowski, T., see Harmeyer and Michalowski ...................... 107

Miettinen, P.V.A., V.A. Rainio, S. A. Kukronen and J.J. Setälä: Finnish Dairy Cows:

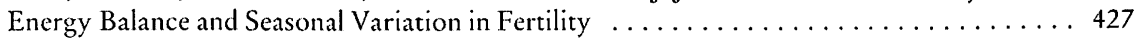

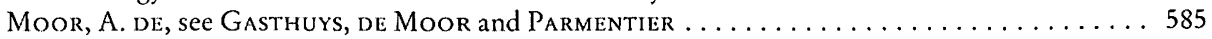

Moor, A. de, see also Gasthuys, de Moor and Parmentier $\ldots \ldots \ldots \ldots \ldots \ldots \ldots \ldots \ldots$

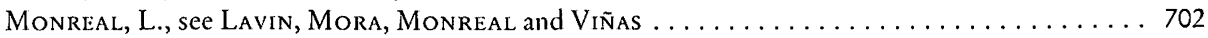

Moor, A. de, see Gasthuys, de Moor and Parmentier .................... 203

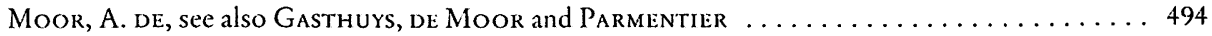

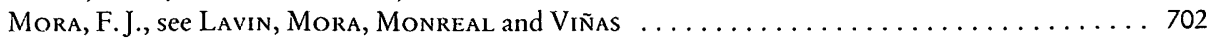

Moseley, T. A., see Giri, Stabenfeldt, Moseley, Graham, Bruss, BonDurant, Cullor and

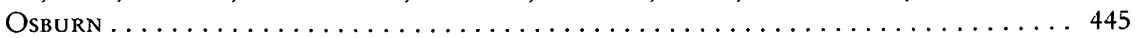

Motyl, T., B. Srwecka, W. Kukulska, A. Orzechowski and R. Puchala: Urinary Excretion of

Purines in Sheep with Experimental Orotic Aciduria . . . . . . . . . . . . . . . . . . 198

Mouligneau, F., see Genicot, Mouligneau und Lekeux $\ldots \ldots \ldots \ldots \ldots \ldots \ldots \ldots \ldots$

Mouwen, J. M. V. M., see Egrerts, Vellenga, van Dijk and Mouwen . . . . . . . . . . . . 157

Müller, E., see Arbeiter, Dobretsberger, Müller und Holzmann . . . . . . . . . . . . 696

Murray, R. D.: Concurrent Conjunctivitis and Placentitis in Aborted Bovine Fetuses . . . . . 660

Murthy, D. K., see Peshin, Sharifi, Patil, Singh, Singh, Singh, Singh and Murthy . . . . 580

Neumann, R., see Kinne, Johannsen, Neumann, Mehlhorn and Pfützener . . . . . . . 306

Neumann, R., see also Johannsen, Menger, Kinne, Neumann, Mehlmorn und Pfützner . . . 321

Nicholson, T., and M. BelkhiRı: The Inhibition of the Reticular Groove Reflex in Sheep by

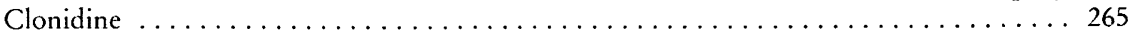

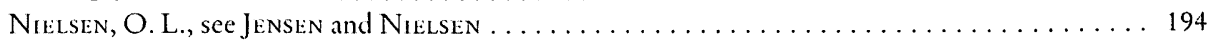

Nigam, J. M., see Gogol, Nigam, Peshin, Sharift and Patil $\ldots \ldots \ldots \ldots \ldots \ldots \ldots \ldots 44$

Nunez-OchoA, L., see VRins, Doucet and NunEz-OchoA . . . . . . . . . . . . . 472

Olnowski, A. A., see Rousseaux, Olkowski, Chauvet, Gooneratne and Christenson . . . . 229

Orzechowski, A., see Motyl, Siwecka, Kukulska, Orzechowski and Puchala . . . . . . 198

Osburn, B.J., see Giri, Stabenfeldt, Moseley, Graham, Bruss, BonDurant, Cullor and

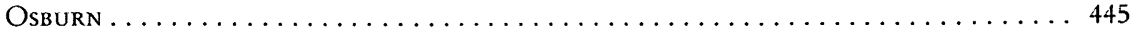

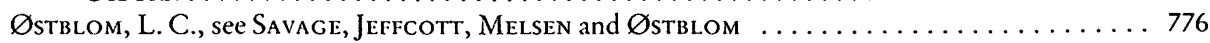

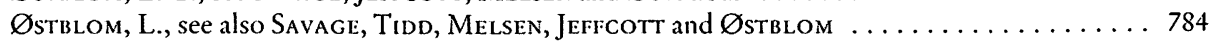

Østblom, L. C., see also Savage, Tidd, Østblom, Melsen and JefFcott . . . . . . . . . . 793

Oyeiwale, J. O., A. A. SAnni and H. A. Ajibade: Effects of Temperature, $\mathrm{pH}$ and Blood Storage

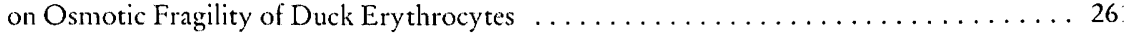

Paczoska-Eliasiewicz, H., and J.Rząsa: Serotonin Levels in the Hen Ovarian Follicles after

Methallibure (I. C. I. 33, 828) Treatment ........................ 187

Parmentier, D., see Gasthuys, de Moor and Parmentier . . . . . . . . . . . . . 203

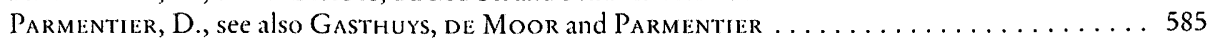

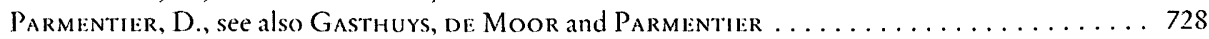

Patil, D. B., see Gogol, Nigam, Peshin, Sharifi and Patil .................. 544

Patil., D. B., see also Peshin, Sharili, Patil, Singh, Singh, Singh, Singh and Murthy ..... 580

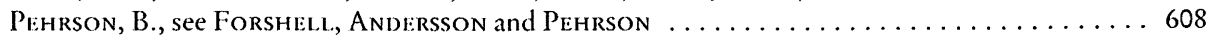

Peshin, P. K., Davood Sharifi, D. B. Patil, Sheela Singh, Harcharan Singh, Jit Singh, A.P. Singh and D. K. MurThY: Evaluation of Triflupromazine as a Sedative in Camels (Camelus dromedarius) . .................................. 580

Pleshin, P. K., see Gogoi, Nigam, Peshin, Sharifi and Patil . . . . . . . . . . . . . 544

PETRY, H.: Untersuchungen zur Freßaktivität, Spontanaktivität und Körperkerntemperatur von Braunrücken-Tamarinen (Saguinus fuscicollis). (Studies on Eating Behaviour, Spontaneous Activity, and Body Temperature in Saddle Back Tamarins (Saguinus fuscicollis/) . . . . . . .

Petrersson, Ann: Cyclic Variations in Intraluminal Pressure in the Isthmus of the Oviduct in Unrestrained Gilts . . . . . . . . . . . . . . . . . . . . . . . . . 337

Pettersson, A., B.Larsson and S. Einarsson: The Effect of Unilateral Ovariectomy on

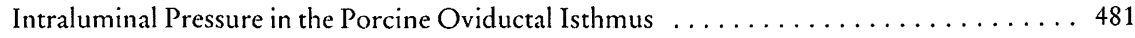

Pfützner, H., see Kinne, Johannsen, Neumann, Mehlhorn and Pfützner . . . . . . . . . 306

Piützner, H., see also Johannsen, Menger, Kinne, Neumann, Mehlyorn und Prützner . . . 321

PLym Forshell, K., L. Andersson and B. Pehrson: The Relationships between the Fertility of

Dairy Cows and Clinical and Biochemical Measurements, with Special Reference to

Plasma Glucose and Milk Acetone . . . . . . . . . . . . . . . . . . . . . . 608

Pokniak, J., see Cornejo, López, Pokniak, González and Corderro ............... 126 


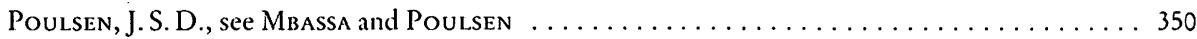

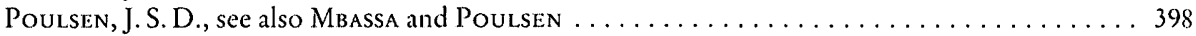

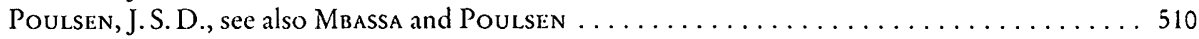

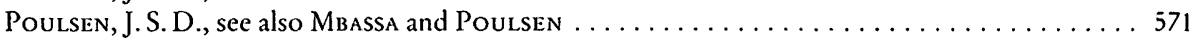

Poulsen, J.S. D., see also Mbassa and Poulsen ........................... 676

Puchala, R., see Motyl, Sitwecka, Kukulska, Orzechowski and Puchala . . . . . . . 198

Raekallio, Marja, Outi Vainio and Mika Scheinin: Detomidine Reduces the Plasma Catecholamine, but not Cortisol Concentrations in Horses . . . . . . . . . . . . 153

Rainio, V. A., see Miettinen, Rainio, Kukkonen and Setälä . . . . . . . . . . . . +27

Ramadan, R.O., A.A. Gameel, E.A. Dafalla and A. K. A. Galil: Bilateral Scrotal Hys-

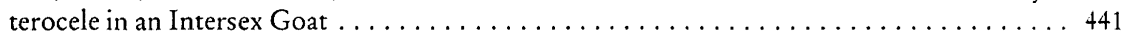

Rambeck, W. A., see Kohn, Erben, Weiser, Rambeck and Zucker . . . . . . . . . . 54

Reifinger, M., see Mayr, Gilli, Schleger, Reifinger and Burtscher ............ 141

Reusch, Claudia, R. Vochezer and E. Weschta: Enzyme Activities of Urinary Alanine Aminopeptidase (AAP) and N-Acetyl- $\beta$-D-Glucosaminidase (NAG) in Healthy Dogs . . 90

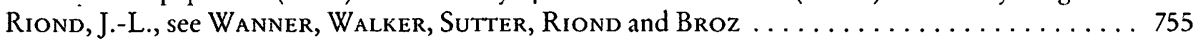

Rodriguez-Martinez, H., see Söderquist, Rodriguez-Martinez and Janson . . . . . . 165

Rodriguez-Martinez, H., see also Stanchev, Rodriguez-Martinez, Albihn, Eriksson,

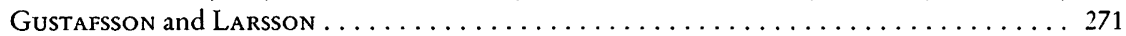

Rodriguez-Martinez, see also Bwanga, Hofmo, Grevle, Einarsson and Rodriguez-

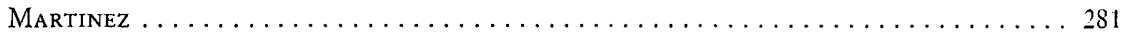

Rodriguez-Martinez, H., see also Hurst, Dalin and Rodriguez-Martinez . . . . . . . 594

Rojkittikhun, T., S. Einarsson and H. Kindahl: A Technique for Continuously Monitoring Hormone Levels in Lactating Sows and Results Obtained Using it to Study LH Release . . 344

Rollin, F., see Amory, Linden, Desmecht, Rollin, Genicot and Lekeux . . . . . . . . . . 409

Rose, D. M., S. N. Giri, J.S. Cullor and R. B. Bushnell: The Combined Use of Lipoxygenase and Cyclooxygenase Inhibitors in Klebsiella pneumoniae-induced Bovine Mastitis .......

Rousseaux, C. G., A. A. Olkowski, A. Chauvet, S. R. Gooneratne, and D. A. Christenson: Ovine Polioencephalomalacia Associated With Dietary Sulphur Intake . . . . . . . . . . 229

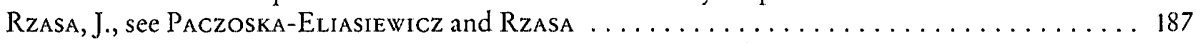

SANDH, G.: Modification of the Cutting Thread Technique for Intestinal Anastomoses using

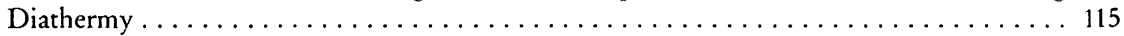

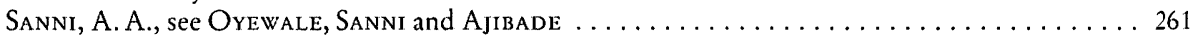

Savage, C.J., L. B. Jeffcott, F. Melsen and L.C. Østblom: Bone Biopsy in the Horse.

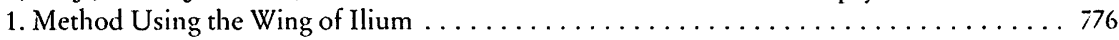

Savage, C.J., L.C. Tidd, F.Melsen, L. B. Jeffcott and L. Østblom: Bone Biopsy in the Horse. 2. Evaluation of Histomorphometric Examination . . . . . . . . . . . . 784

Savage, C. J., L. C. Tidd, L. C. Østblom, F. Melsen and L. B. Jeffcott: Bone Biopsy in the Horse. 3. Normal Histomorphometric Data According to Age and Sex . . . . . . . . . . 793

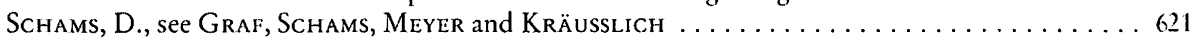

Scharrer, E., see Langhans, Scharrer and Meyer $\ldots \ldots \ldots \ldots \ldots \ldots \ldots \ldots \ldots \ldots \ldots \ldots$

Scharrer, E., see also Denac, Kümin and Scharrer $\ldots \ldots \ldots \ldots \ldots \ldots \ldots \ldots \ldots \ldots \ldots$

Scheinin, M., see Raekallio, Vainio and Scheinin . . . . . . . . . . . . . . . . . 153

Schleger, W., see Mayr, Gilli, Schleger, Reifingler and Burtscher $\ldots \ldots \ldots \ldots \ldots \ldots$ i 1

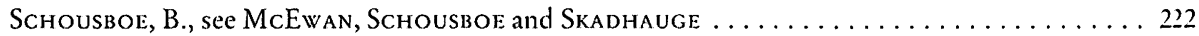

Schranner, I., see Kaspers, Schranner and Lösch $\ldots \ldots \ldots \ldots \ldots \ldots \ldots \ldots \ldots \ldots \ldots \ldots$

Schrauwen, E., see Cox, Schrauwen, Cools and Houvenaghel . . . . . . . . . . 418

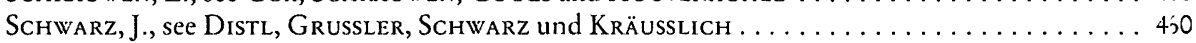

Schweigert, F. J., Stephanie Uehlein-Harrell, Giesela v. Hegel and H. Wiesner: Vitamin A (Retinol and Retinyl Esters), $\alpha$-Tocopherol and Lipid Levels in Plasma of Captive Wild

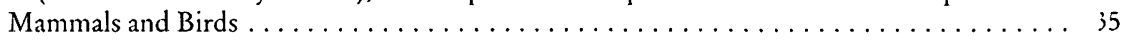

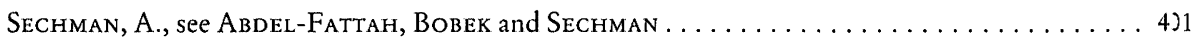

Setälä, J.J., see Miettinen, Rainio, Kukkonen and Setälä . . . . . . . . . . . . 4.7

Sharifi, D., see Gogoi, Nigam, Peshin, Sharifi and Patil . . . . . . . . . . . . 544

Sharifi, D., see also Peshin, Sharifi, Patil, Singh, Singh, Singh, Singh and Murthy . . . . . 530

Silva, N., G. Farias y J.M. Torres: Caracterización del Colágeno del Disco Intervertebral Canino por la Reacción del N-Metil-Benzotiazolidon-Hidrazona. (Characterization of Collagen in Canine Intervertebral Discs Using the 3-Methyl-Benzothiazol-2-on-hydra-

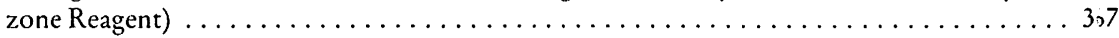

Singh, A. P., see Peshin, Sharifi, Patil, Singh, Singh, Singh, Singh and Murthy . . . . 530 
Singh, H., see Peshin, Sharifi, Patil, Singh, Singh, Singh, Singh and Murthy . . . . . 580

Singh, J., see Peshin, Sharifi, Patil, Singh, Singh, Singh, Singh and Murthy . . . . . . . . 580

Singh, J., see Peshin, Sharifi, Patil, Singh, Singh, Singh, Singh aild Murthy . . . . . . . 580

Siw ecka, B., see Motry, Siwecka, Kukulska, Orzechowski and Puchala . . . . . . . . . 198

Skadhauge, E., see McEwan, Schousboe and Skadhauge . . . . . . . . . . . . . . . . 222

Söderquist, L., H. Rodriguez-Martinez and L. Janson: Post-Thaw Motility, ATP Content and Cytochrome C Oxidase Activity of A. I. Bull Spermatozoa in Relation to Fertility . . . 165

Söderquist, L., L. Janson, K. Larsson and S. Einarsson: Sperm Morphology and Fertility in

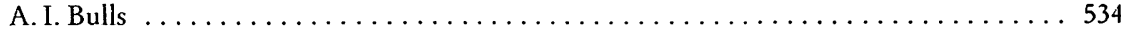

Soraci, A. L., see Errecalde, Lanusse, Mestorino, Landoni and Soraci . . . . . . . . . 255

Spiess, B., see Daicker, Gywat, Keller, Spiess und Brückner . . . . . . . . . . . . . 652

Stabenfeldt, G. H., see Giri, Stabenfeldt, Moseley, Graham, Bruss, BonDurant, Cullor

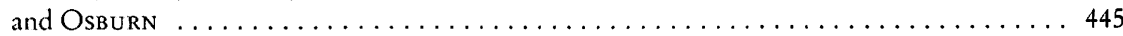

Stanchev, P.D., H. Rodriguez-Martinez, A. Albihn, H. Eriksson, H. Gustafsson and K. Larsson: Concentrations of Nuclear Progesterone Receptors in Endometrium of Virgin and Repeat Breeder Heifers after Embryo Transfer . . . . . . . . . . . . . . . 271

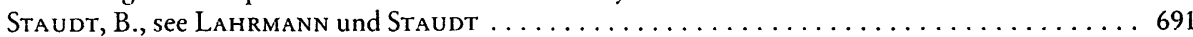

Stein, H., see Cihak, Ziegler-Heitbrock, Stein and Lösch $\ldots \ldots \ldots \ldots \ldots \ldots \ldots \ldots \ldots$

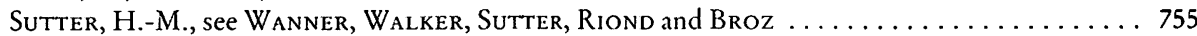

Takeya, G., see AnJiki, Takeya, Hashimoto and Kadota . . . . . . . . . . . . . . . 770

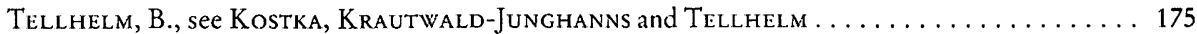

Tidd, L. C., see Savage, Tidd, Melsen, JefFcott and Østblom .................. 784

Tidd, L. C., see also Savage, Tidd, Østblom, Melsen and Jeffcott . . . . . . . . . . . . . 793

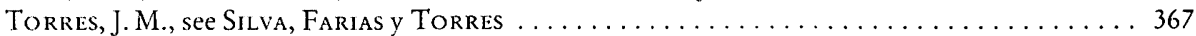

Troyer, D. L., J. Ayers, H. Wollen, H. W. Leipold and J.E. Cook: Gross, Microscopic and Ultrastructural Lesions of Protoporphyria in Limousin Calves . . . . . . . . . . 300

Uehlein-Harrell, St., see Schweigert, Uehlein-Harrell, v. Hegel and Wiesner . . . . . 35

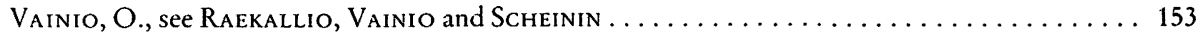

Vellenga, L., see Egberts, Vellenga, van Dijk and Mouwen $\ldots \ldots \ldots \ldots \ldots \ldots \ldots \ldots \ldots$

Vochezer, R., see Reusch, Vochezer and Weschta . . . . . . . . . . . . . . . . . 90

VRins, A., M. Doucet and L. Nunez-OchoA: A Retrospective Study of Bronchoalveolar Lavage Cytology in Horses with Clinical Findings of Small Airway Disease . . . . . . . . . 472

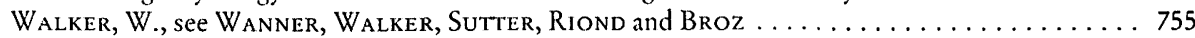

Wanner, M., W. Walker, H.-M. Sutter, J.-L. Riond and J. Broz: Influence of Dietary Citric Acid and Calcium on the Bioavailability of Orally Administered Chlortetracycline in

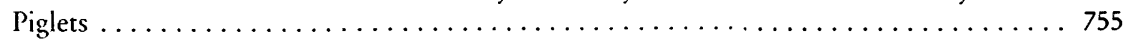

WECHTA, E., see REUSCH, VOCHEZER and WESCHTA ..................... 90

Weiser, H., see Kohn, Erben, Weiser, Rambeck and Zucker . . . . . . . . . . . . . . . . . 54

Wiesner, H., see Schweigert, Uehlein-Harrell, v. Hegli and Wiesner $\ldots \ldots \ldots \ldots \ldots \ldots$

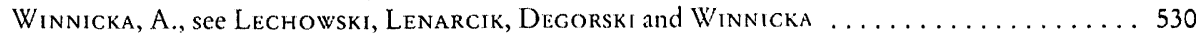

Wittmann, J., see Kaltiner, Heydner and WitTimann ..................... 43

Wollen, H., see Troyer, Ayers, Wollen, LlitPol.d and CoOK ............... 300

Zentek, J., K. DÄMmRich und H. Meyer: Untersuchungen zum Cu-Mangel beim wachsenden Hund. (Investigations on Copper Deficiency in Growing Dogs) . . . . . . . . . . . 561

Zepperitz, H., G. Jahreis, H. Kiupel and V. Hess:: The Effects of Intramuscularly Administered Vitamin $\mathrm{D}_{3}, 25$ - and $1 \alpha$-Hydroxycholecalciferol in Cows on Plasma Mineral Content, Plasma 25-Hydroxycholecalciferol and on Mineral Deposits in Soft Tissues . . . . 763

Ziegler-Heitbrock, H. W. L., see Cihak, Ziegler-Heirbrock, Stilin and Lösch . . . . . . . 28

Zucker, H., see Kohn, Erben, Weiser, Rambeck and Zucker . . . . . . . . . . . . . . . 54 


\section{Short Communications / Kurze Mitteilungen}

Kaneko, M., see Matsuda, Koyama, Oikawa, Toshihara and Keneko . . . . . . . . 557

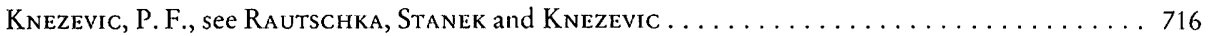

Koyama, H., see Matsuda, Koyama, Oikawa, Toshihara and Kaneko . . . . . . . . . 557

Oikawa, M., see Matsuda, Koyama, Oikawa, Toshihara and Kaneko . . . . . . . . . 557

Matsuda, H., H. Koyama, M. Orkawa, T. Yoshimara and M. Kaneko: Nerve Growth Factor-

like Activity Detected in Equine Peripheral Blood after Running Exercise . . . . . . . . . 557

Rautschka, R., Ch. Stanek and P. F. Knezevic: Plasma Histamine Levels in Laminitic Horses

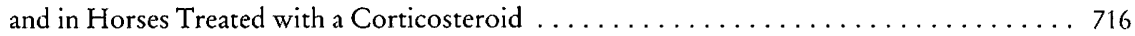

Stafford, K. J.: Ruminoreticular Motility in Ewes during Pregnancy and Lactation . . . . . . 798

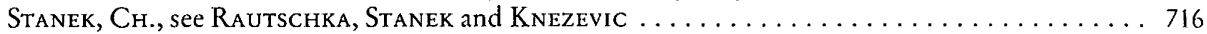

Yoshimara, T., see Matsuda, Koyama, Oikawa, Toshihara and Kaneko . . . . . . . . 557 


\section{Book Reviews / Buchbesprechungen}

Eikmeier, H., E. Fellmer und H. Moegle: Lehrbuch der Gerichtlichen Tierheilkunde. Tierarzt und Gericht - Tierkauf - Haftpflicht - Sorgfaltspflichten - Tierversicherung Tierschutz - Doping - Berufs- und Standesrecht - Öffentliches Veterinärwesen . . . . . 399

Fowler, Murray E.: Medicine and Surgery of South America Camelids. Llama - Alpaca -

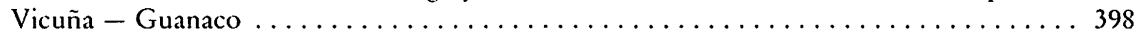

Kirchgessner, M. (Hrsg.): Tiermodelle für die menschliche Ernährungsphysiologie. Fortschritte in der Tierphysiologie und Tierernährung, Nr. $20 \ldots \ldots \ldots \ldots \ldots \ldots \ldots 480$

Mlyer, H.: Beiträge zum Wasser- und Mineralstoffhaushalt des Pferdes. Fortschritte in der Tierphysiologie und Tierernährung - Advances in Animal Physiology and Animal

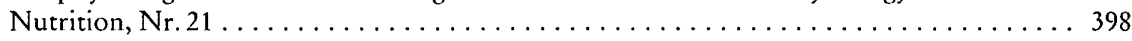

Miller, H. R. P.: Immunity to and diagnosis of internal parasitism. OIE Scientific and Technical Review, Volume 9, No. 2. Office International des Epizooties, Paris. 1990 . . . . . . . . . . 399

Moulton, J. E. (editor): Tumors in Domestic Animals. 3. Auflage . . . . . . . . . . . . . 640

Office International des Epizooties (O.I.E.), Revue Scientifique et Technique Vol.9, No.1, 1990. Bovine Virus Diarrhoea. Coordinated by J. Brownlie and M. C. Clarke ....... 480

Pliska, V., and G. Stranzinger: Farm Animals in Biomedical Research. Advances in Animal Breeding and Genetics - Fortschritte der Tierzüchtung und Züchtungsbiologie, Bd. 5 . . . 639

Rosenberger, Gustav: Die klinische Untersuchung des Rindes. 3., neubearbeitete und erweiterte Auflage. Herausgegeben von G.Dirksen, H.-D. Gründer, M.Stöber. Unter

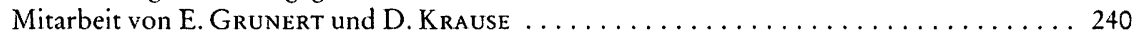

Rüsse, I., und F. Sinowatz: Lehrbuch der Embryologie der Haustiere. 473 Seiten, 318 Abbildungen mit 710 Einzeldarstellungen, davon 83 mehrfarbig, und 39 Tabellen . . . . . . . 720

Hugo Stünzi/Eugen Weiss: Allgemeine Pathologie für Tierärzte und Studierende der Tiermedizin. 8., neubearbeitete Auflage . . . . . . . . . . . . . . . . . . . . . . 560

WILSON, R. T.: Ecophysiology of the Camelidae and Desert Ruminants . . . . . . . . . . . . . 560 
${ }^{1}$ Institute of Physiology, Physiological Chemistry and Nutrition Physiology, Veterinary Faculty, Ludwig-Maximilians-Universität München, and ${ }^{2}$ Münchner Tierpark Hellabrunn, Germany

\title{
Vitamin A (Retinol and Retinyl Esters), $\alpha$-Tocopherol and Lipid Levels in Plasma of Captive Wild Mammals and Birds ${ }^{1}$
}

\author{
F. J. Schweigert ${ }^{1 *}$, Stephanie Uehlein-Harrell ${ }^{1}$, Giesela v. Hegel ${ }^{2}$ and H. Wiesner ${ }^{2}$ \\ Address of authors: 'Institute of Physiology, Physiological Chemistry and Nutrition Physiology, \\ Veterinary Faculty, Ludwig-Maximilians-Universität München, \\ Veterinärstr. 13, W-8000 München 22, and \\ ${ }^{2}$ Münchner Tierpark Hellabrunn, Tierparkstr. 30, W-8000 München 90, FRG \\ * Present address: Department of Physiology, Technische Universität München, \\ W-8050 Freising-Weihenstephan, Vöttingerstr. 45, FRG
}

With 2 tables

(Received for publication August 10, 1990)

\section{Summary}

Vitamin A (retinol and retinyl esters), vitamin $\mathrm{E}$ and lipids were determined in a wide variety of wild mammals and birds held in captivity. In mammals plasma levels of vitamin A were generally below $500 \mathrm{ng} / \mathrm{ml}$ and those of vitamin $\mathrm{E}$ were highly variable $(0.1-2 \mu \mathrm{g} / \mathrm{ml})$. In primates, vitamin $\mathrm{E}$ levels were 3 to $8 \mu \mathrm{g} / \mathrm{ml}$. Whereas in Marsupalia, Chioptera, primates, Rodentia, Proboscidea, Sirenia, Perissodactyla and Artiodactyla only retinol was found, retinyl esters (basically retinol palmitate/ oleate) represented 10 to $50 \%$ of the total plasma vitamin $\mathrm{A}$ in some birds of the order Ciconiiformes and Falconiformes. Retinol levels in birds were higher compared to mammals $(500-2,000 \mathrm{ng} / \mathrm{ml})$. The same was true for lipids as well as for vitamin E levels $(1-26 \mu \mathrm{g} / \mathrm{ml})$ in the plasma of birds.

\section{Introduction}

Recent studies on vitamin A transport in blood plasma showed that there are distinct differences within the animal kingdom. Especially in the order of carnivores, a nonspecific transport of vitamin A esters by lipoproteins seems to be physiological and not associated with any signs of vitamin A intoxication (SCHWEIGERT, 1988; SCHWEIGERT et al., 1990). These novel observations raise the question as to whether this phenomenon is unique for the order Carnivora or whether other species show similar peculiarities in vitamin A transport. Although vitamin A levels of numerous species are known, difficulties in their interpretation arise from the methods of determination used. Based on the knowledge that vitamin $\mathrm{A}$ is transported under physiological conditions nearly exclusively as retinol ( $>95 \%$ of total vitamin A), most of the methods used so far have only considered the alcoholic form of vitamin A. In carnivores, for example, this would yield values which would be 60-99\% too low. In this paper, therefore, vitamin A (retinol and retinyl esters),

This paper is dedicated to Professor Dr. Michael Merkenschlager on the occasion of his 65th birthday. 
vitamin $\mathrm{E}$ and lipids were determined in a wide variety of wild mammals and birds held in captivity. Additionally, numerous diseases associated with vitamin A or E deficiency are known in wild animals held in captivity (KonstantrNov and IPPEN, 1979; ZwarT et al., 1979; Kočı, 1982; LiU et al., 1983; LiU and DolenseK, 1986; for a review on vitamin E see DIERENFELD, 1989). Their evaluation would benefit from the knowledge of normal vitamin $\mathrm{A}$ and $\mathrm{E}$ plasma values, which are rather rare in literature.

\section{Material and Methods}

Plasma or serum samples were obtained from wild animals kept in captivity under various housing and feeding conditions at the zoological gardens in München (Tierpark Hellabrunn, $\mathrm{ZH}$ ), the zoological gardens in Nürnberg (ZN), the Institut für Geflügelkrankheiten (Veterinary Faculty) (GK), the Pettenkofer Institute (PI), a falconry (Jagdfalkenhof Schloß Rosenburg) (F) and the local slaughterhouse. Samples were frozen between $-20^{\circ}$ and $-70^{\circ} \mathrm{C}$ and stored until further analyzed. Lyophilized serum of the rattle snake (pooled) was obtained from Sigma (St. Louis, MO, USA).

Vitamins $A$ and $E$ were determined with an isocratic reversed-phase high-performance liquid chromatography (HPLC) system as described elsewhere (SCHWEIGERT, 1990). Briefly, vitamins A and $E$ were extracted from the serum or plasma and separated on a RP-18 column $(4 \times 125 \mathrm{~mm}, 5 \mu \mathrm{m})$ using methanol as the eluent at a flow rate of $1 \mathrm{ml} / \mathrm{min}$. Vitamin A was detected at $313 \mathrm{~nm}$ and a fluorescence spectrophotometer was used to quantify vitamin $E$ ( $\alpha$-tocopherol). Wavelength settings were 295 and $330 \mathrm{~nm}$ for excitation and emission, respectively. $\beta$-Carotene was separated on straight-phase HPLC as described (Vuilleumier et al., 1983). Retinol, retinol palmitate, retinol stearate, $\alpha$-tocopherol and $\beta$-carotene were identified and quantified by comparison of retention time as well as peak areas with external standards. Recovery was more than $93 \%$ for all components. The detection limit for retinol, retinyl esters and $\alpha$-tocopherol was $2 \mathrm{ng}, 3.5 \mathrm{ng}$ and $2.4 \mathrm{ng}$, respectively and $2 \mathrm{ng}$ for $\beta$-carotene. Cholesterol, triglycerides and phospholipids were measured by enzymatic methods using commercial assay reagents (Boehringer Mannheim, FRG).

\section{Results}

Table 1 summarizes the results for retinol, $\alpha$-tocopherol and lipid in the plasma of different species in the order of Marsupalia, Chioptera, primates, Rodentia, Proboscidea, Sirenia, Perissodactyla and Artiodactyla. Retinyl esters were only detectable in traces in Marsupalia and in primates, especially in animals of the species tamarin $(71 \pm 94 \mathrm{ng} / \mathrm{ml}$, retinol equivalent). $\beta$-Carotene was only present in the plasma of animals found in the orders Perissodactyla (wild horse, $377 \pm 594 \mathrm{ng} / \mathrm{ml}$; kulan, traces; domestic donkey, $183 \mathrm{ng} / \mathrm{ml}$; mountain zebra, traces) and Artiodactyla (cow, $1,021 \pm 880 \mathrm{ng} / \mathrm{ml}$; gaur, $1,826 \mathrm{ng} / \mathrm{ml}$ ). Retinol levels in the plasma were generally lower than $500 \mathrm{ng} / \mathrm{ml}$. In bats only traces of retinol could be detected. Contrary to this, levels of $\alpha$-tocopherol were highly variable. In nearly all plasma samples of the investigated species, phospholipids represent the majority of lipids followed by cholesterol and triglycerides. In birds (Table 2) not only retinol but in some species of the order Ciconiiformes and Falconiformes, retinyl esters were detected as well. The dominant ester fraction was retinyl palmitate/oleate. Samples of birds were not investigated for $\beta$-carotene. Both $\alpha$-tocopherol and lipids were much higher in birds compared to mammals. The only reptile investigated - a rattle snake (Crotalus spp.) - had a low level of retinol $(23 \mathrm{ng} / \mathrm{ml})$. $\alpha$-Tocopherol, phospholipids and triglycerides were found to be $8.44 \mu \mathrm{g} / \mathrm{ml}, 1.28$ and $1.62 \mathrm{mg} / \mathrm{ml}$, respectively.

\section{Discussion}

In the present study almost 250 serum or plasma samples from a fairly wide range of wild mammals and birds (59 species) held in captivity were investigated for their levels of fat-soluble vitamins $\mathrm{A}$ and $\mathrm{E}$ as well as lipids. Despite this large number of samples, differences in age, sex, nutritional status and environment as well as sampling and sample handling make comparison difficult not only within the material of this study, but also with results reported by others. The only variables in this study which are known to show very little effect on the concentration of fat-soluble vitamins are the kind of sample (plasma vs. serum) as well as sample storage and transportation (CrAFT et al., 1988). 
Table 1. Vitamin A, $\alpha$-tocopherol and lipid levels in plasma of mammals

\begin{tabular}{|c|c|c|c|c|c|c|}
\hline Species & $\mathrm{n}$ & $\begin{array}{l}\text { Retinol } \\
\mathrm{ng} / \mathrm{ml}\end{array}$ & $\begin{array}{l}\alpha \text {-Tocopherol } \\
\mu \mathrm{g} / \mathrm{ml}\end{array}$ & Phospholipids & $\begin{array}{l}\text { Cholesterol } \\
\mathrm{mg} / \mathrm{ml}\end{array}$ & Triglycerides \\
\hline \multicolumn{7}{|l|}{ Marsupalia $(\mathrm{ZH})$} \\
\hline Red kangaroo (Macropus rufus) & 6 & $146 \pm 44$ & $1.81 \pm 0.35$ & $1.56 \pm 0.26$ & $0.92 \pm 0.20$ & $0.76 \pm 0.15$ \\
\hline Wallaroo (Macropus robustus) & 2 & $134 / 109$ & $0.27 / 0.26$ & $1.61 / 1.59$ & $0.92 / 0.92$ & $1.19 / 0.52$ \\
\hline Doria's tree kangaroo (Dendroagus dorianus) & 1 & 197 & 1.02 & 2.04 & 1.10 & 0.33 \\
\hline Pretty-face wallaby (Protemnodon elegans) & 3 & $157 \pm 37$ & $2.52 \pm 2.09$ & $2.32 \pm 0.76$ & $1.37 \pm 0.37$ & $0.73 \pm 0.29$ \\
\hline White-throated wallaby (Protemnodon parma) & 1 & 126 & 0.18 & 1.13 & 0.72 & 0.81 \\
\hline Common opossum (Didelphis marsupialis) (S) & 1 & 21 & 1.48 & 1.71 & 1.48 & 0.33 \\
\hline \multicolumn{7}{|l|}{ Chioptera (ZI) } \\
\hline Naked-backed bat (Pteronotus pannellii) & 1 & traces & 0.16 & 0.39 & 0.31 & 0.10 \\
\hline Horseshoe bat (Rbinolophus rouxi) & 5 & traces & $0.25 \pm 0.28$ & $0.40 \pm 0.32$ & $0.14 \pm 0.09$ & $0.34 \pm 0.18$ \\
\hline \multicolumn{7}{|l|}{ Primates } \\
\hline Siamang (Hylobates syndactylus) $(\mathrm{ZH})$ & 2 & $440 / 445$ & $8.02 / 5.84$ & nd & nd & nd \\
\hline Common marmoset (Callithrix jacchus) (PI) & 15 & $125 \pm 79$ & $6.00 \pm 10.35$ & nd & nd & nd \\
\hline Brown-headed tamarin (Saguinus fuscicollis)(PI) & 17 & $90 \pm 63$ & $3.30 \pm 2.47$ & nd & nd & nd \\
\hline \multicolumn{7}{|l|}{ Rodentia } \\
\hline Rat (Rattus rattus) & 6 & $188 \pm 36$ & $6.17 \pm 2.10$ & $1.62 \pm 0.31$ & $0.95 \pm 0.10$ & $1.09 \pm 0.42$ \\
\hline \multicolumn{7}{|l|}{ Proboscidea $(\mathrm{ZH})$} \\
\hline African elephant (Loxodonta africana) & 1 & 38 & 0.12 & 0.90 & 0.55 & 0.59 \\
\hline Indian elephant (Elephas maximus) & 1 & 45 & 0.06 & 0.44 & 1.04 & 0.46 \\
\hline \multicolumn{7}{|l|}{ Sirenia } \\
\hline Manatee (Trichechus manatus) (ZN) & 1 & 35 & 1.60 & 2.23 & 1.92 & 0.75 \\
\hline \multicolumn{7}{|l|}{ Perissodactyla $(\mathrm{ZH})$} \\
\hline Horse (Equus caballus) & 14 & $213 \pm 60$ & $1.30 \pm 0.54$ & nd & $0.78 \pm 0.13$ & nd \\
\hline Wild horse (Equus przewalskii) & 6 & $163 \pm 43$ & $1.21 \pm 0.35$ & $1.11 \pm 0.48$ & $0.68 \pm 0.37$ & $0.32 \pm 0.16$ \\
\hline Kiang (Equus bemionus kiang) & 5 & $101 \pm 17$ & $1.64 \pm 0.73$ & $0.56 \pm 0.12$ & $0.58 \pm 0.15$ & $0.09 \pm 0.04$ \\
\hline Kulan (Equus bemionus kulan) & 8 & $139 \pm 41$ & $0.78 \pm 0.30$ & $0.70 \pm 0.32$ & $0.81 \pm 0.40$ & $0.26 \pm 0.16$ \\
\hline Domestic donkey (Equus asinus asinus) & 1 & 179 & 2.00 & 1.66 & 0.92 & 0.73 \\
\hline
\end{tabular}


Somalian wild ass (Equus asinus somalicus)

Mountain zebra (Equus zebra hartmannae)

Artiodactyla ( $\mathrm{ZH})$

Domestic pig (Sus scrofa domesticus)

Vicugna (Vicugna vicugna)

Fallow deer (Dama dama dama)

Barasingha (Cervus duvauceli)

Red deer (Cervus elaphus)

Père David's deer (Elaphurus davidianus)

Moose (Alces alces)

Nilgai (Boselaphus tragocamelus)

Domestic ox (Bos taurus)

Gaur (Bos gaurus)

Blesbok (Damaliscus dorcas philippsi)

Dama gazelle (Gazella dama mborr)

Chamois (Rupicapra rupicapra)

Ibex (Capra ibex)

Markhor (Capra falconeri)

Wild goat (Capra aegagrus hircus)

Mouflon (Ovis ammon musimon)

Domestic sheep (Ovis ammon aries)
1.03

1.85

0.39

$1.51 \pm 0.36$
0.32
0.98
0.21
$0.76 / 0.65$
$1.71 / 1.32$
$0.95 \pm 0.26$
0.96
$2.30 \pm 0.74$
0.60
0.49
$0.89 \pm 0.52$
$0.79 \pm 0.40$
$0.67 \pm 0.30$
$1.58 \pm 1.16$
0.26
0.10
0.57

$1.07 \pm 0.15$

0.36

1.28

0.70

$0.50 / 0.48$

$0.78 / 0.60$

$0.83 \pm 0.40$

$132 / 114$

$297 \pm 21$

279

$308 \pm 53$

40

428

$489 \pm 98$

$1939 \pm 2915$

$815 \pm 36$

$435 \pm 108$

297

260

302

$.57 \pm 0.27$

0.52

$0.48 \pm 0.16$

$0.78 \pm 0.34$

$0.71 \pm 0.13$

$0.89 \pm 0.31$

1.12

0.46

0.78
0.64

0.52

$\begin{array}{ll}0.92 \pm 0.09 & 0.35 \pm 0.17 \\ 0.29 & 0.24 \\ 0.79 & 0.15 \\ 0.55 & 0.29 \\ 0.37 / 0.36 & 0.08 / 0.05 \\ 0.58 / 0.45 & 0.18 / 0.12 \\ 0.50 \pm 0.22 & 0.21 \pm 0.06 \\ 0.45 & 0.08 \\ 1.56 \pm 0.32 & 0.14 \pm 0.04 \\ 0.77 & 0.17 \\ 0.27 & 0.07 \\ 0.44 \pm 0.14 & 0.28 \pm 0.78 \\ 0.46 \pm 0.20 & 0.22 \pm 0.24 \\ 0.50 \pm 0.20 & 0.32 \pm 0.66 \\ 0.73 \pm 0.27 & 0.44 \pm 0.38 \\ 0.69 & 0.47 \\ 0.29 & 0.65 \\ 0.51 & 0.35\end{array}$

Code: $\mathrm{ZH}=$ Zoological garden Hellabrunn - München; $\mathrm{ZN}=$ zoological garden Nürnberg; PI = Pettenkofer Institut; $\mathrm{S}=\mathrm{Sigma}$ Chemicals. nd = not determined. The results can be converted into SI units by using the following factors: retinol 0.0035 (ng/ml into $\mu \mathrm{mol} / \mathrm{l}$ ); $\alpha$-tocopherol 2.32 ( $\mu \mathrm{g} / \mathrm{ml}$ into $\mu \mathrm{mol} / \mathrm{l}$ ); phospholipids 1.29 ; cholesterol 2.59; triglyceride 1.15 (all $\mathrm{mg} / \mathrm{ml}$ into $\mathrm{mmol} / \mathrm{l}$ ).

0.35 
Table 2. Vitamin A, $\alpha$-tocopherol and lipid levels in plasma of birds

\begin{tabular}{|c|c|c|c|c|c|c|c|c|}
\hline Species & $\mathrm{n}$ & Retinol & $\begin{array}{l}\text { R.palmitatel } \\
\text { oleate } \\
\mathrm{ng} / \mathrm{ml}\end{array}$ & R. stearate & $\begin{array}{l}\alpha \text {-Tocopherol } \\
\mu \mathrm{g} / \mathrm{ml}\end{array}$ & Phospholipids & $\begin{array}{l}\text { Cholesterol } \\
\mathrm{mg} / \mathrm{ml}\end{array}$ & Triglycerides \\
\hline \multicolumn{9}{|l|}{ Pelecaniformes $(\mathrm{ZH})$} \\
\hline $\begin{array}{l}\text { Eastern white pelican (Pelecanus onocro- } \\
\text { talus) }\end{array}$ & 1 & 692 & - & - & 8.42 & 3.06 & 1.55 & 1.00 \\
\hline Dalmatian pelican (Pelecanus crispus) & 1 & 580 & - & - & 15.69 & 3.40 & 1.36 & 0.87 \\
\hline \multicolumn{9}{|l|}{ Ciconiiformes (ZN) } \\
\hline White stork (Ciconia ciconia) & 1 & 245 & 103 & - & 2.98 & 2.83 & 1.60 & 0.57 \\
\hline Black stork (Ciconia nigra) & 1 & 768 & 144 & - & 9.00 & 1.95 & 1.52 & 1.04 \\
\hline Hermit ibis (Geronticus eremita) & 3 & $502 \pm 11$ & - & - & $7.86 \pm 0.96$ & $2.77 \pm 0.39$ & $1.75 \pm 0.28$ & $0.44 \pm 0.03$ \\
\hline \multicolumn{9}{|l|}{ Falconiformes (GK) } \\
\hline Sparrowhawk (Accipiter nisus) & 2 & $1664 / 1129$ & $276 /-$ & $87 /-$ & $24.87 / 24.17$ & $4.69 / 3.41$ & $3.45 / 2.24$ & $4.13 / 0.59$ \\
\hline Goshawk (Accipiter gentilis) & 2 & $1824 / 1144$ & $683 /$ traces & $210 /-$ & $25.96 / 7.32$ & $3.66 / 2.07$ & $3.38 / 2.29$ & $0.94 / 0.65$ \\
\hline Common buzzard (Buteo buteo) (F) & 1 & 804 & 110 & - & 22.77 & nd & 4.07 & 1.36 \\
\hline Bonelli's eagle (Hiëraaëtus fasciatus) & 1 & 1454 & 875 & 71 & 37.91 & 3.29 & 2.30 & 0.92 \\
\hline Golden eagle (Aquila chrysaëtos) & 1 & 1232 & 138 & - & 13.52 & 3.71 & 1.73 & 2.64 \\
\hline Lanner falcon (Falco biarmicus) & 2 & $2111 / 1340$ & $132 /$ traces & traces & $40.74 / 19.38$ & $3.67 / 2.46$ & $2.51 / 1.69$ & $1.09 / 1.05$ \\
\hline Saker falcon (Falco chergus) & 1 & 1440 & 472 & 64 & 1.95 & 5.41 & 2.24 & 2.54 \\
\hline Peregrine falcon (Falco peregrinus) & 3 & $1026 \pm 297$ & $86 \pm 135$ & traces & $5.30 \pm 5.37$ & $4.94 \pm 1.30$ & $2.68 \pm 0.49$ & $1.52 \pm 0.68$ \\
\hline Common kestrel (Falco tinnunculus) & 2 & $1194 / 821$ & $577 / 505$ & traces & $27.45 / 8.97$ & $3.74 / 3.42$ & $1.99 / 1.40$ & $1.57 / 1.32$ \\
\hline \multicolumn{9}{|l|}{ Galliformes } \\
\hline Chicken (Gallus gallus domesticus) & $10 *$ & $357 \pm 96$ & - & - & $2.86 \pm 1.28$ & $2.07 \pm 0.28$ & $1.33 \pm 0.47$ & $0.37 \pm 0.05$ \\
\hline & $7 * *$ & $797 \pm 214$ & traces & - & $4.10 \pm 2.02$ & $4.57 \pm 1.97$ & $0.85 \pm 0.29$ & $11.42 \pm 6.09$ \\
\hline Quail (Coturnix coturnix) & 11 & $817 \pm 127$ & - & - & $1.74 \pm 0.69$ & $5.03 \pm 0.53$ & $1.26 \pm 0.16$ & $7.13 \pm 1.43$ \\
\hline Turkey (Meleagris gallopavo) & 12 & $1099 \pm 327$ & traces & - & $2.40 \pm 0.98$ & $2.20 \pm 0.36$ & $1.30 \pm 0.28$ & $0.53 \pm 0.22$ \\
\hline \multicolumn{9}{|l|}{ Gruiformes } \\
\hline Red-crowned crane (Grus japonensis) ( $\mathrm{ZH})$ & 1 & 101 & - & - & 1.04 & nd & nd & nd \\
\hline \multicolumn{9}{|l|}{ Strigiformes } \\
\hline Eagle-owl (Bubo bubo) (GK) & 4 & $299 \pm 67$ & traces & - & $0.79 \pm 0.60$ & $1.86 \pm 0.83$ & $1.06 \pm 0.28$ & $2.38 \pm 0.83$ \\
\hline Tawny owl (Strix aluco) (F) & 1 & 526 & traces & - & 20.64 & nd & nd & nd \\
\hline
\end{tabular}

The amounts of retinyl esters in plasma are expressed as the equivalent weight of retinol. Code: $\mathrm{ZH}=$ Zoological garden Hellabrunn $-\mathrm{München} ; \mathrm{ZN}=$ zoological garden Nürnberg; GK = Institut für Geflügelkrankheiten, Veterinary Faculty München; F = Falconry. * imature chickens; ** mature female chickens; nd = not determined. The 
Lipids as well as the fat-soluble vitamins $\mathrm{A}$ and $\mathrm{E}$ have to be transported in the aqueous environment of blood by protein carriers. For the investigated plasma components two different types of carrier exist. Vitamin $\mathrm{E}$ as well as the lipids are transported by the lipoproteins with a species specific distribution among the lipoprotein fractions (Kirkeby, 1966; Galster et al., 1977; Leat et al., 1979). For vitamin A, a specific carrier protein - the retinol-binding protein (RBP) - exists. This carrier protein is of importance for the homeostatic level of retinol, the physiological transport form of vitamin $A$, in the blood. Because of the homeostasis of retinol in the blood, changes in vitamin A levels are only observed if either stores (liver) are heavily depleted or animals suffer from hypervitaminosis A (SMITH and Goodman, 1979). Contrary to this, vitamin $\mathrm{E}$ in the blood, carried by lipoproteins, is clearly affected by the intake of vitamin $\mathrm{E}$ with the food (Willetr et al., 1983) as well as the lipid levels in the blood (Davies et al., 1969). Therefore, vitamin $\mathrm{E}$ status can be monitored by measuring the vitamin $\mathrm{E}$ plasma level, while vitamin A levels are less useful in the assessment of the vitamin status.

We were the first to show that, contrary to the assumption that lipoprotein-bound retinyl esters are responsible for the signs of vitamin A intoxication (Mallia et al., 1975; SMith and Goodman, 1976), in a whole order of mammals (Carnivora) a high percentage of retinyl esters is bound to plasma lipoproteins and seems to be a physiological way of vitamin A transport (SCHWEIGERT, 1988; SCHWEIGERT et al., 1990). This study now shows, that in most of the investigated species, only retinol - very probably bound to the specific carrier, the RBP - was present in plasma. The levels observed $(<500 \mathrm{ng} / \mathrm{ml})$ were in the order of magnitude of levels reported by others (BAKER et al., 1986; BAKER et al., 1988; Ghebremeskel and Williams, 1988). It is interesting to note that in bats which were obviously healthy, only trace amounts of retinol were detected. Further investigations would be needed to determine whether, in the animal kingdom, this indicates another peculiarity in vitamin A metabolism. In birds, retinol values were higher ranging from 500 to $2,000 \mathrm{ng} / \mathrm{ml}$ and in addition, similar to carnivores, in most species of the order Ciconiiformes and Falconiformes, retinyl esters (mainly retinyl palmitate/oleate) were detected ranging between 10 to $50 \%$ of total vitamin A (calculated as retinol equivalents) in plasma. Similar to carnivores, birds with a high percentage of retinyl esters in the blood showed no signs of a vitamin A intoxication. The similarity between carnivorous mammals and birds with regard to the occurrence of vitamin A esters in the blood might indicate that the occurrence of vitamin A esters, probably bound to lipoproteins (GANGULY et al., 1952), is an adaptation of vitamin $\mathrm{A}$ metabolism to an ample supply with vitamin $\mathrm{A}$ in a carnivorous diet. The high percentage of retinyl esters in blood plasma of the Bonelli's eagle, the golden eagle and the common kestrel, however, may be caused by the application of Tricrescovit ${ }^{\circledR}$ (Rhone Merieux) a vitamin preparation. Contrary to previous reports on the vitamin A transport in the blood plasma of chickens, where retinyl esters represented $75 \%$ of total vitamin A (Ganguly et al., 1952) no vitamin A esters could be detected in this study. Even in mature female chickens only traces of esters were present despite a drastic increase in the total plasma lipids due to changes in lipid metabolism with the onset of egg laying which is responsible for the observed high lipid levels (especially triglycerides) in quails too (SCHJEIDE, 1963).

$\beta$-Carotene was only found in a few species in the order of Artiodactyla and Perissodactyla. These differences between white- and yellow-fat species are summarized by GooDwIN (1984). It can only be speculated that the occurrence of white- and yellow-fat species within the same family - despite comparable feed - might be due to specific intracellular carrier proteins in the enterocytes (GANGULY et al., 1959) limited to only a few species in which the local supplementation of peripheral target tissue may be of importance e.g. in fertility (SCHWEIGERT and ZuCKER, 1988).

Since vitamin $E$ levels in plasma are readily affected by the vitamin $E$ supplementation and lipid levels in blood (Davies et al., 1969; Willetr et al., 1983), results for vitamin E were highly variable but comparable to values obtained by others (CARAvAGGI, 1969; LIU et al., 1983; Baker et al., 1986; Baker et al., 1988; Dierenfeld and Dolensek, 1988; 
Dierenfeld et al., 1989). Higher values in primates compared to the other mammals are similar to other primates (AUSMAN and Hayes, 1974; MCGuire et al., 1989) and comparable to those found in man (Vuilleumier et al., 1983; Willett et al., 1983). The much higher levels in birds ( 1 to $26 \mu \mathrm{g} / \mathrm{ml}$ ) compared to mammals correspond to known data (CAlle et al., 1989) may be due to much higher lipid levels in plasma, since both are strongly dependant (Davies et al., 1969).

In most of the investigated species, phospholipids represented the majority of lipids followed by cholesterol and triglycerides. Both, the rather high concentration of lipids in birds and the phospholipids as dominating fraction of total lipids, correspond to known data obtained from a variety of species (DANGERFIELD et al., 1976). Lipid values found for the African or Indian elephant correspond well to those obtained from wild animals (BROWN and WHITE, 1979).

Nevertheless, despite the above mentioned variables, certain tendencies within different orders are obvious for fat-soluble vitamins as well as for lipids. For vitamin A, plasma levels in the majority of species ranged from 100 to $500 \mathrm{ng} / \mathrm{ml}$. Lower levels were found in bats, manatees and their closest terrestrial relatives the elephants. In birds and carnivores (SCHWEIGERT et al., 1990), much higher retinol levels can be observed. Especially the occurrence of vitamin A esters in carnivores, as well as in certain orders of birds should not be interpreted as signs of vitamin A oversupplementation. For vitamin E, the known relationship of plasma vitamin E levels with lipid levels in the blood have to be considered when vitamin $\mathrm{E}$ status is assessed by measuring the plasma levels of vitamin $\mathrm{E}$. Thus, species with low lipid levels tend to lower vitamin E levels (ungulates, rodents, Marsupalia and Proboscidea) compared to those with high lipid levels such as primates, carnivores, pinnipeds and birds.

\section{Acknowledgements}

We would like to thank the following persons and institutions for supplying us with samples: Dr. A. Gaukler (Zoo Nürnberg), Mr. V. Walter (Jagdfalkenhof Schloß Rosenburg), Dr. M. Vater (Zoologisches Institut der Ludwig-Maximilians-Universität München), Dr. C.I. FLuRER, and Dr. F. Grimm (Institut für Geflügelkrankheiten, Tierärztliche Fakultät der LMU-München). This work was supported by Hoffmann-La Roche, Basel, Switzerland.

\section{References}

Ausman, L.M., and K.C. Hayes, 1974: Vitamin E deficiency anemia in Old and New World monkeys. Am. J. Clin. Nutr. 27, 1141-1151.

Baker, H., B. DE ANGelis, and O. Frank, 1988: Vitamins and uther metabolites in various sera commonly used for cell culturing. Experientia 44, 1007-1010.

Baker, H., S. M. Schorr, B.D. Murphy, B. De Angelis, S. Feingol.d, and O. Frank, 1986: Blood vitamin and choline concentrations in healthy domestic cats, dogs and horses. Am. J. Vet. Res. $47,1468-1471$.

Brown, I. R. F., and P. T. WhItE, 1979: Serum electrolytes, lipids and cortisol in the African elephant, Loxodonta africana. Comp. Biochem. Physiol. 62 A, 899-901.

Calle, P.P., E.S. Dierenfeld, and M.E. Robert, 1989: Serum $\alpha$-tocopherol in raptors fed vitamin E-supplemented diets. J. Zoo Wildl. Med. 20, 62-67.

CaravagGi, C., 1969: Vitamin E concentrations in the serum of various experimental animals. Comp. Biochem. Physiol. 30, 585-588.

Craft, N.E., E.D. Brown, and J. C. SMith, Jr., 1988: Effects of storage and handling conditions on concentrations of individual carotenoids, retinol and tocopherol in plasma. Clin. Chem. 34, $44-48$.

Dangerfield, W.G., R. Finlayson, G. Myatt, and M.G. Mead, 1976: Serum lipoproteins and atherosclerosis in animals. Atherosclerosis 25, 95-106.

Davies, T., J. Kelleher, and M.S. LosowsKY, 1969: Interrelation of serum lipoprotein and tocopherol levels. Clin. Chim. Acta 24, 431-436.

Drerenfeld, E.S., 1989: Vitamin E deficiency in zoo reptiles, birds, and ungulates. J. Zoo Wildl. Med. 20, 3-11. 
Dierenfeld, E.S., and E.P. Dolensek, 1988: Circulating levels of vitamin E in captive Asian elephants (Elephas maximus). Zoo Biol. 7, 165-172.

Dierenfeld, E.S., R. Du Tort, and R.E. Miller, 1988: Vitamin E in captive and wild black rhinoceros (Diceros bicornis). J. Wildl. Dis. 24, 547-550.

Galster, W., and P.MorRison, 1977: Plasma lipid levels and lipoprotein ratios in ten rodent species. Comp. Biochem. Physiol. 58 B, 39-42.

Ganguly, J., N. I. Krinsky, J. W. Mehl, and H.J. Deuel, Jr., 1952: Studies on the distribution of vitamin $\mathrm{A}$ as esters and alcohol and of carotenoids in plasma proteins of several species. Arch. Biochem. Biophys. 38, 275-282.

Ganguly, J., S. KrishnamurThy, and S. Mahadevan, 1959: The transport of carotenoids, vitamin A and cholesterol across the intestines of rats and chickens. Biochem. J. 71, 756-762.

Ghebremeskel, K., and G. Williams, 1988: Plasma retinol and alpha-tocopherol levels in captive wild animals. Comp. Biochem. Physiol. 89 B, 279-283.

Goodwin, T.W., 1984: The Biochemistry of the Carotenoids. London: Chapman and Hall.

Kirkeby, K., 1966: Total lipids and lipoproteins in animal species. Scan. J. Clin. Lab. Invest. 18, $437-442$.

Kočı, P., 1982: Muscle disease in Grevy's zebra colts (Equus grevyi). 24. Int. Symp. Erkrank. Zootiere, $61-64$.

Konstantinov, A., und R. Ippen, 1979: Vitamin-A-Mangel bei Zoo- und Wildvögeln. 21. Int. Symp. Erkrank. Zootiere, 41-46.

Leat, W.M.F., C.A. Northrop, N. Buttress, and D. M. Jones, 1979: Plasma lipids and lipoproteins of some members of the order perissodactyla. Comp. Biochem. Physiol. 63 B, 275-281.

Liu, S.-K., and E. Dolensek, 1986: Cardiomyopathy and vitamin E deficiency in zoo animals. Lab. Invest. 54, $37 \mathrm{~A}$.

Liu, S.-K., E.P. Dolensek, C.R. Adams, and J.P. TAPpe, 1983: Myelopathy and vitamin E deficiency in six Mongolian wild horses. J. Am. Vet. Med. Assoc. 183, 1266-1268.

Mallia, A. K., J.E. Smith, and D.S. Goodman, 1975: Metabolism of retinol-binding protein and vitamin A during hypervitaminosis A in the rat. J. Lipid. Res. 16, 180-188.

McGuire, J.T., E.S. Dierenfeld, R.H. Poppenga, and W.E. Brazelton, 1989: Plasma alphatocopherol, retinol, cholesterol, and mineral concentrations in captive gorillas. J. Med. Primatol. $18,155-161$.

Schjeide, O.A., 1963: Progress in the chemistry of fats and other lipids. Holman, R.T., W.O. Lindberg, and T.Malkin (eds.), vol.6, Pergamon Press; Oxford, London, New York, Paris, pp. 253-284.

SCHWEIGERT, F.J., 1988: Insensitivity to dogs of the effects of nonspecific bound vitamin A in plasma. Int. J. Vit. Nutr. Res. 58, $23-25$.

SCHWEIGERT, F.J., 1990: Effect of gestation and lactation on lipoprotein pattern and composition in dairy cows. J. Anim. Physiol. Anim. Nutr. 63, 75-83.

SCHWEIGERT, F.J., O. A. RYDER, W. A. RAMBECK, and H.ZuCKer, 1990: The majority of vitamin A is transported as retinyl esters in blood of most carnivores. Comp. Biochem. Physiol. $95 \mathrm{~A}$, $573-578$.

SCHWEIGERT, F. J., and H.ZUCKer, 1988: Concentrations of vitamin A, $\beta$-carotene and vitamin E in individual bovine follicles of different quality. J. Reprod. Fert. 82, 575-579.

SMrTH, F. R., and D.S. Goodman, 1976: Vitamin A transport in human vitamin A toxicity. N. Engl. J. Med. 294, 805-808.

Smrth, J.E., and D.S. Goodman, 1979: Retinol-binding protein and the regulation of vitamin A transport. Federation Proc. 38, 2504-2509.

Vuilleumier, J.-P., H.E. Keller, D. Gysel, and F. Hunziker, 1983: Clinical chemical methods for the routine assessment of the vitamin status in human populations. Part I: The fat-soluble vitamins $A$ and $E$, and $\beta$-carotene. Int. J. Vit. Nutr. Res. 53, 265-272.

Willett, W.C., M.J. Stampfer, B.A. Underwood, J. O. Taylor, and C. H. Hennekens, 1983: Vitamins A, E, and carotene: effects of supplementation on their plasma levels. Am. J. Clin. Nutr. 38, 559-566.

Zwart, P., W.H.P. Schreurs, and G. M. Dorrestein, 1979: Vitamin A deficiency in parrots. 21. Int. Symp. Erkrank. Zootiere, 47-52. 